Prepared in cooperation with the U.S. Agency for International Development, Office of U.S. Foreign Disaster Assistance (USAID/OFDA)

\title{
A Software Tool for Rapid Flood Inundation Mapping
}
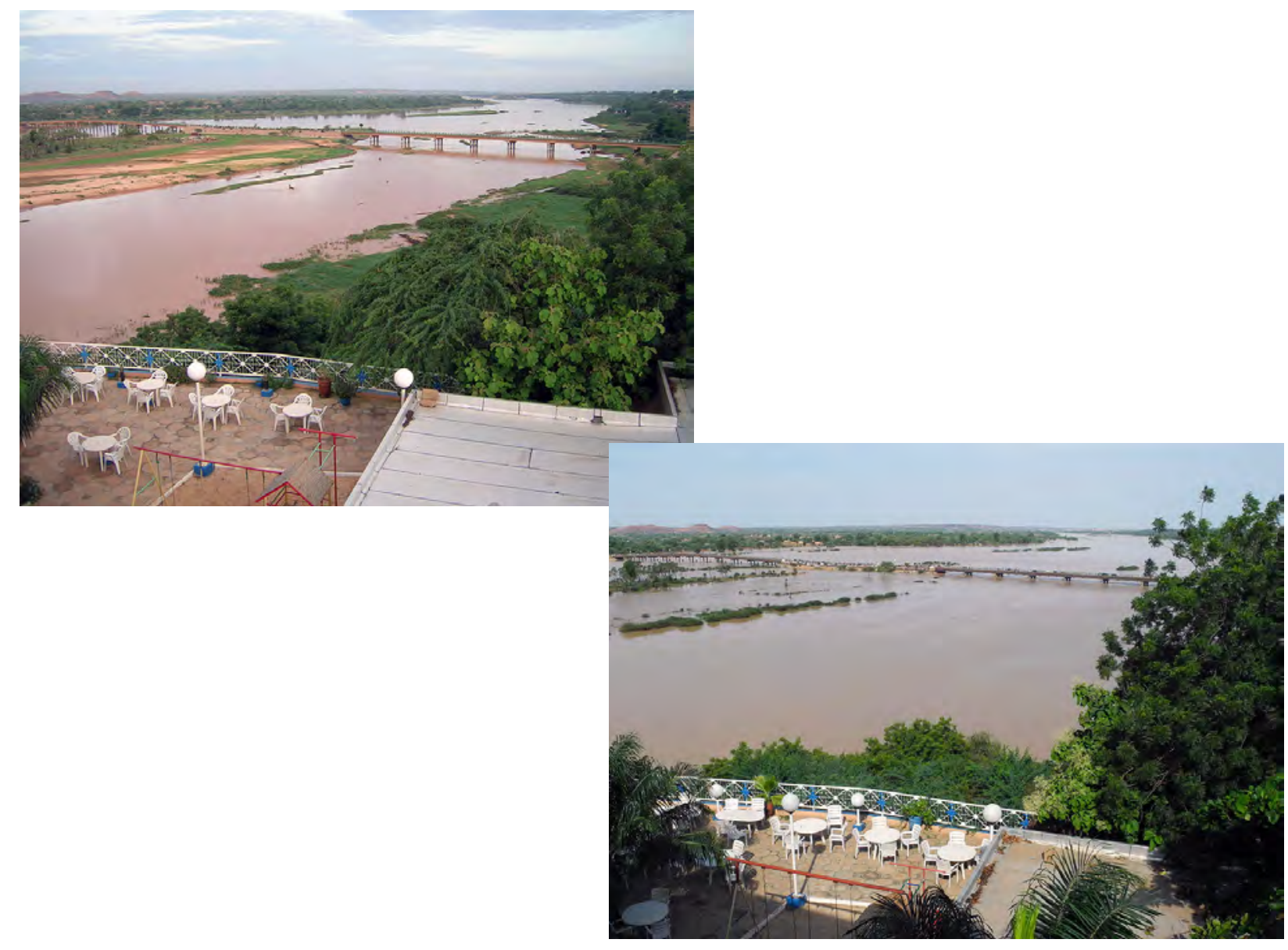

Open-File Report 2016-1038 
Cover photographs. The Niger River at Niamey in July 2004 with a discharge of about 300 cubic meters per second (top left) and during the flooding in September 2012 with a discharge of about 2,500 cubic meters per second (bottom right). The flooding of 2012 was the greatest since record keeping began in 1929. Photographs by Gray Tappan, U.S. Geological Survey. 


\section{A Software Tool for Rapid Flood Inundation Mapping}

By James Verdin, Kristine Verdin, Melissa Mathis, Tamuka Magadzire, Eric Kabuchanga, Mark Woodbury, and Hussein Gadain

Prepared in cooperation with the U.S. Agency for International Development, Office of U.S. Foreign Disaster Assistance (USAID/OFDA)

Open-File Report 2016-1038 


\section{U.S. Department of the Interior SALLY JEWELL, Secretary}

\section{U.S. Geological Survey Suzette M. Kimball, Director}

\section{U.S. Geological Survey, Reston, Virginia: 2016}

For more information on the USGS - the Federal source for science about the Earth, its natural and living resources, natural hazards, and the environment—visit http://www.usgs.gov or call 1-888-ASK-USGS.

For an overview of USGS information products, including maps, imagery, and publications, visit http://store.usgs.gov

Any use of trade, firm, or product names is for descriptive purposes only and does not imply endorsement by the U.S. Government.

Although this information product, for the most part, is in the public domain, it also may contain copyrighted materials as noted in the text. Permission to reproduce copyrighted items must be secured from the copyright owner.

Suggested citation:

Verdin, James; Verdin, Kristine; Mathis, Melissa; Magadzire, Tamuka; Kabuchanga, Eric; Woodbury, Mark; and Gadain, Hussein, 2016, A software tool for rapid flood inundation mapping: U.S. Geological Survey Open-File Report 2016-1038, 26 p., http://dx.doi.org/10.3133/ofr20161038.

ISSN 2331-1258 (online) 


\section{Contents}

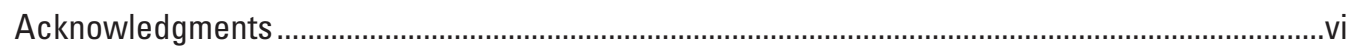

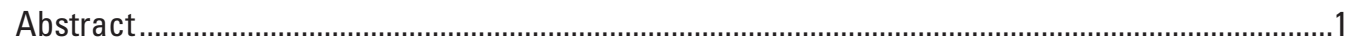

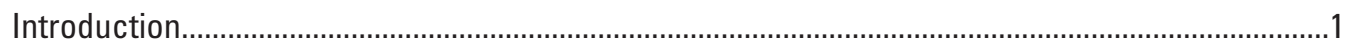

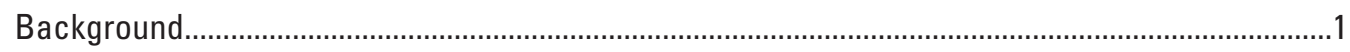

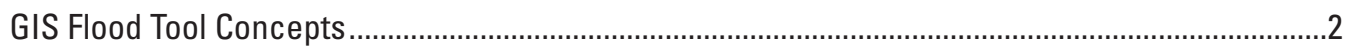

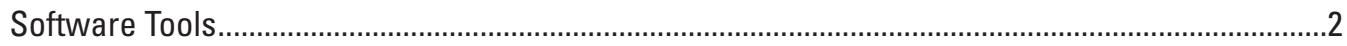

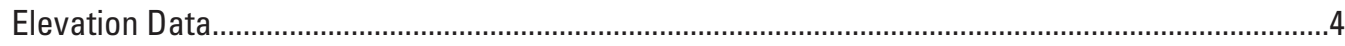

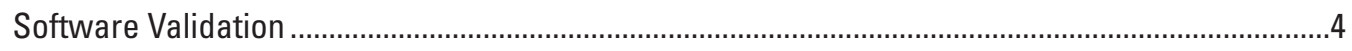

Comparisons within the United States .................................................................................5

Comparisons Outside of the United States................................................................................13

Okavango River near Rundu, Namibia ............................................................................13

Blue Nile River in Sudan .................................................................................................13

Applications of the GIS Flood Tool Software...............................................................................13

Global Assessment Report on Disaster Risk Reduction..........................................................20

Somalia Water and Land Management Information Management Flood-Risk Maps............20

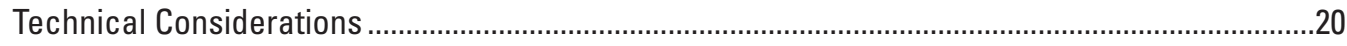

Importance of Digital Elevation Model Resolution and Quality ...............................................20

Placement and Number of Cross Sections ..........................................................................24

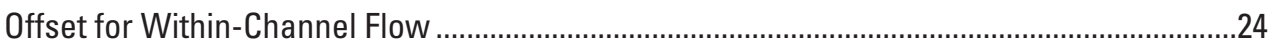

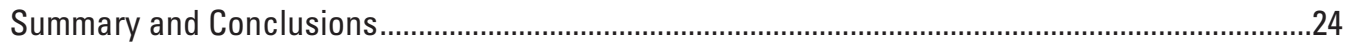

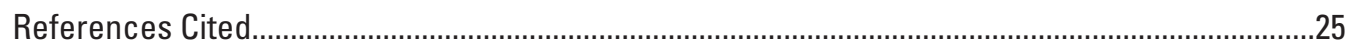




\section{Figures}

1. Diagram showing the concept of a Relative digital elevation model .3

2. Screen shot showing an empty ArcGIS interface with the GIS Flood Tool .3

3. Map showing a comparison of the results of the GIS Flood Tool and one-dimensional hydraulic modeling for Des Plaines River at Lincolnshire, Illinois .........5

4. Map showing a comparison of the results of the GIS Flood Tool and one-dimensional hydraulic modeling for East Fork White River near Bedford, Indiana...

5. Map showing a comparison of the results of the GIS Flood Tool and one-dimensional hydraulic modeling for lowa River at lowa City, lowa.

6. Map showing a comparison of the results of the GIS Flood Tool and one-dimensional hydraulic modeling for Leaf River at Hattiesburg, Mississippi

7. Map showing a comparison of the results of the GIS Flood Tool and one-dimensional hydraulic modeling for Mississippi River near St. Paul, Minnesota ...10

8. Map showing a comparison of the results of the GIS Flood Tool and one-dimensional hydraulic modeling for Saddle River at Lodi, New Jersey.

9. Map showing a comparison of the results of the GIS Flood Tool and one-dimensional hydraulic modeling for Saluda River at Greenville, South Carolina ....12

10. Map showing a comparison of the results of the GIS Flood Tool and one-dimensional hydraulic modeling for Suncook River at North Chichester, New Hampshire

11. Map showing a comparison of the results of the GIS Flood Tool and one-dimensional hydraulic modeling for Susquehanna River at Harrisburg, Pennsylvania

12. Map showing a comparison of the results of the GIS Flood Tool and one-dimensional hydraulic modeling for Wabash River at Terre Haute, Indiana

13. Map showing a comparison of the results of the GIS Flood Tool (GFT) and one-dimensional hydraulic modeling for West Branch Susquehanna River at Jersey Shore, Pennsylvania

14. Maps showing flooding on the Okavango River near Rundu, Namibia on March 25,2009

15. Screen shot showing comparison of GIS Flood Tool inundation pattern to patterns from the HEC-RAS study along the southern part of the Blue Nile River in Sudan, East Africa.

16. Screen shot showing comparison of GIS Flood Tool inundation pattern to patterns from the HEC-RAS study along the northern part of the Blue Nile River in Sudan, East Africa...

17. Screen shot showing map of the likely inundation pattern for the 50-year flood at Afgooye, Somalia, on the Shabelle River near Mogadishu, prepared by FAO SWALIM using the GIS Flood Tool....

18. Maps showing comparison of the flood inundation maps produced with the GIS Flood Tool for the Juba River at Luuq in Somalia

19. Maps showing inundation patterns generated for a discharge of 3,370 cubic meters per second for the West Branch Susquehanna River at Jersey Shore, Pennsylvania 


\section{Tables}

1. U.S. Geological Survey gaging station names, location, information, and areal correspondence between GIS Flood Tool and one-dimensional hydraulic

\section{Conversion Factors}

[International System of Units to U.S. customary units]

\begin{tabular}{lcl}
\hline \multicolumn{1}{c}{ Multiply } & By & \multicolumn{1}{c}{ To obtain } \\
\hline meter $(\mathrm{m})$ & Length & foot $(\mathrm{ft})$ \\
kilometer $(\mathrm{km})$ & 3.281 & mile $(\mathrm{mi})$ \\
\hline \multicolumn{3}{c}{ Flow rate } \\
\hline cubic meter per second $\left(\mathrm{m}^{3} / \mathrm{s}\right)$ & 35.31 & cubic foot per second $(\mathrm{ft} 3 / \mathrm{s})$ \\
meters per second $(\mathrm{m} / \mathrm{s})$ & 3.281 & foot per second $(\mathrm{ft} / \mathrm{s})$ \\
\hline & Hydraulic gradient & \\
\hline meter per kilometer $(\mathrm{m} / \mathrm{km})$ & 5.27983 & foot per mile $(\mathrm{ft} / \mathrm{mi})$ \\
\hline
\end{tabular}

\section{Datum}

Vertical coordinate information is referenced to the North American Vertical Datum of 1988 (NAVD 88) or the National Geodetic Vertical Datum of 1929 (NGVD 29).

Horizontal coordinate information is referenced to the North American Datum of 1983 (NAD 83).

Elevation, as used in this report, refers to distance above the vertical datum. 


\section{Abbreviations}

ASTER GDEM Advanced Spaceborne Thermal Emission and Reflection Radiometer Global Digital Elevation Model

CIMA Centro Internazionale in Monitoraggio Ambientale

DEM digital elevation model

EROS Earth Resources Observation and Science

FAO Food and Agriculture Organization

FEMA Federal Emergency Management Agency

FEWS NET Famine Early Warning Systems Network

FIM Flood Inundation Mapping Program

GFT GIS Flood Tool

GIS Geographic Information System

HEC-RAS Hydrologic Engineering Center River Analysis System

lidar light detection and ranging

NED National Elevation Dataset

NWS National Weather Service

OFDA Office of U.S. Foreign Disaster Assistance

RCMRD Regional Center for Mapping of Resources for Development

RTi Riverside Technology, Inc.

SRTM Shuttle Radar Topography Mission

SRTM-FM SRTM for Flood Mapping

SWALIM Somalia Water and Land Information Management

UNEP GRID United Nations Environment Programme's Global Resource Information Database

UNISDR United Nation's International Strategy for Disaster Risk Reduction

USAID U.S. Agency for International Development

USGS U.S. Geological Survey

\section{Acknowledgments}

The authors wish to gratefully acknowledge the support and encouragement of Dr. A. Sezin Tokar, Hydrometeorlogical Hazards Advisor at the U.S. Agency for International Development's Office of U.S. Foreign Disaster Assistance (USAID/OFDA), Washington, D.C. The authors are also indebted to Dr. Kwabena Asante and Dr. Md. Shahriar Pervez, whose early flood inundation mapping efforts for USAID in Afghanistan set the stage for development of this software tool, as well as the numerous authors of the Flood Inundation Mapping studies cited in this report. 


\title{
A Software Tool for Rapid Flood Inundation Mapping
}

\author{
By James Verdin, ${ }^{1}$ Kristine Verdin,' Melissa Mathis, ${ }^{2}$ Tamuka Magadzire, ${ }^{3}$ Eric Kabuchanga, ${ }^{4}$ Mark \\ Woodbury, ${ }^{5}$ and Hussein Gadain ${ }^{6}$
}

\section{Abstract}

The GIS Flood Tool (GFT) was developed by the U.S. Geological Survey with support from the U.S. Agency for International Development's Office of U.S. Foreign Disaster Assistance to provide a means for production of reconnaissance-level flood inundation mapping for datasparse and resource-limited areas of the world. The GFT has also attracted interest as a tool for rapid assessment flood inundation mapping for the Flood Inundation Mapping Program of the U.S. Geological Survey. The GFT can fill an important gap for communities that lack flood inundation mapping by providing a first-estimate of inundation zones, pending availability of resources to complete an engineering study. The tool can also help identify priority areas for application of scarce flood inundation mapping resources. The technical basis of the GFT is an application of the Manning equation for steady flow in an open channel, operating on specially processed digital elevation data. The GFT is implemented as a software extension in ArcGIS. Output maps from the GFT were validated at 11 sites with inundation maps produced previously by the Flood Inundation Mapping Program using standard one-dimensional hydraulic modeling techniques. In 80 percent of the cases, the GFT inundation patterns matched 75 percent or more of the one-dimensional hydraulic model inundation patterns. Lower rates of pattern agreement were seen at sites with low relief and subtle surface water divides. Although the GFT is simple to use, it should be applied with the oversight or review of a qualified hydraulic engineer who understands the simplifying assumptions of the approach.

\footnotetext{
${ }^{1}$ U.S. Geological Survey.

${ }^{2}$ SGT, Inc., Contractor to the U.S. Geological Survey (USGS) Earth Resources Observation and Science (EROS) Center.

${ }^{3}$ Famine Early Warning Systems Network (FEWS NET).

${ }^{4}$ Regional Center for Mapping of Resources for Development (RCMRD).

${ }^{5}$ Riverside Technology Incorporated.

${ }^{6}$ Food and Agriculture Organization, Somalia Water and Land Information Management (SWALIM).
}

\section{Introduction}

The motivations for the Flood Inundation Mapping (FIM) Program are application of flood inundation map libraries for flood preparedness, response, recovery, mitigation planning, and ecological assessments. A library of maps for a river reach that describes the full range of inundation patterns, from bankfull to slightly above the largest recorded flow, is a fundamental resource for all these applications. Such applications to reduce loss of life and property are needed by communities around the world. In spite of their importance, flood inundation map libraries are not available in many places because of cost and technical constraints.

Many communities lack flood inundation mapping with which to build scenarios for mitigation and response planning. Established methods, involving field surveys and hydraulic modeling, are often beyond the means of state and local governments in the United States, and even national governments in the developing world. To address this need, a tool was developed for flood inundation mapping using commonly available topographic data and commercial geographic information system (GIS) software. The resulting GIS Flood Tool (GFT) was validated in many settings, with favorable results demonstrating that it can provide useful initial estimates of flood extent at relatively low cost, while helping to prioritize locations for more thorough engineering studies.

\section{Background}

Flood inundation mapping in the United States is typically done through application of a one-dimensional hydraulic model. This approach requires field surveys of many river cross sections at close intervals to define channel geometry for input to the model, and post processing of modeled stages to interpolate flood inundation maps. The one-dimensional hydraulic modeling approach is the most common methodology used for the FIM Program of the U.S. Geological Survey (USGS) and National Weather Service (National Oceanic and Atmospheric Administration, 2011).

The U.S. Agency for International Development (USAID) Office of U.S. Foreign Disaster Assistance (OFDA) provides resources for emergency response to natural disasters, including floods, to governments in developing countries 
that request help when their own capabilities are insufficient to manage extreme events. Officials in USAID OFDA understand that the cost of response to such events can be reduced through preparedness and mitigation, and for this reason they invest in building the capacity of national agencies, including national meteorological and hydrological services. To help increase capacity for flood rapid assessment, USAID OFDA provided funds to the USGS to develop a software tool for production of first-estimate flood inundation map libraries nearly anywhere in the world using globally available digital elevation data and popular commercial GIS software. The resulting GFT is described in this report, along with results of tests at sites in the United States and several other countries. The GFT is not meant to replace the one-dimensional hydraulic modeling methods that are preferred for developing Flood Inundation Map Libraries, but rather to provide interim results until other studies are considered.

\section{GIS Flood Tool Concepts}

The GFT was developed to operate with digital elevation model (DEM) data to produce patterns of flood inundation corresponding to either a specified river discharge or stage. The GFT involves an implementation of the Manning equation for steady flow in an open channel (Manning, 1891), along with a specially processed "Relative DEM." The Relative DEM simplifies the mapping of the inundation depth onto the landscape. The resulting inundation patterns can be used in conjunction with additional geographic information describing settlement patterns, transportation networks, and land use and land cover to assess vulnerability of areas along streams and rivers to flood events and support planning to mitigate negative effects of flood inundation.

Application of the GFT includes derivation of stream networks from the input DEM that consist of interconnected stream segments, and developing stream cross sections for each stream segment. The Manning equation is used to construct a depth-discharge relationship for each cross section. The Manning equation is written as

$$
V=\frac{1}{n} R^{2 / 3} \sqrt{S}
$$

where

$V \quad$ is the mean velocity of the cross section, in meters per second;

$R \quad$ is the hydraulic radius, in meters (the crosssectional area divided by the wetted perimeter);

$S \quad$ is the slope of the energy line, dimensionless; and

$n \quad$ is the coefficient of roughness ("Manning $n$ "), dimensionless.
Discharge $(Q$, cubic meters per second) is simply the product of $V$ and the cross-sectional area. The GFT use of the Manning equation assumes that, for a given discharge, the surface water depth is uniform along each stream reach. For any stream reach of interest, the GFT builds a depth-discharge relationship using the Manning equation. This depth-discharge relationship is then used within the GFT to translate a userspecified discharge into the corresponding water depth in the river.

Once the depth in the river is determined by application of the Manning equation, or specified directly by the user, the corresponding inundated area is determined using the Relative DEM. The concept of the Relative DEM builds on work by De Roo and others (2007) and Nobre and others (2011). The Relative DEM is a version of the input DEM that has been processed by the GFT to yield elevation values that are expressed as height above the river (fig. 1). The Relative DEM is created in the GFT by using GIS algorithms that condition and process a DEM to allow definition of the interconnectivity among the pixels (by defining which pixels flow to which). Using these algorithms, each nonstream pixel in the DEM is tributary to only one stream pixel. The elevation of the stream pixel is subtracted from the elevation of the nonstream pixels that are tributary to the stream pixel; the stream pixels are assigned the value of zero. This process yields the Relative DEM. The general concept of the Relative DEM is shown in figure 1. The use of the Relative DEM removes the complication of the channel slope to map the inundated extent and, therefore, greatly simplifies flood inundation mapping. With use of the Relative DEM, the inundated extent can be determined using simple map algebra, by selecting only those pixels with values less than the stage to be modeled.

\section{Software Tools}

The GFT is a set of ArcGIS (Esri, 2014) map-based tools. The tools are written in Python and Visual Basic .NET (VB. NET). The GFT was originally written as a "Map Document" in ArcGIS, but was later converted into an ArcGIS "Extension," based on feedback from experimental users. Programming of the ArcGIS Extension was a joint effort between the USGS Earth Resources Observation and Science (EROS) Center, the Regional Center for Mapping of Resources for Development (RCMRD) in Nairobi, and the Famine Early Warning Systems Network (FEWS NET) in Gaborone. As an ArcGIS Extension, portability between platforms is improved and the tools are more stable since the user does not have the ability to inadvertently overwrite the Map Document.

An empty ArcGIS interface with the GFT toolbar is shown in figure 2. The buttons across the toolbar access the tools necessary to run the GFT. The processes that a user needs to follow to successfully execute the GFT are briefly summarized: 

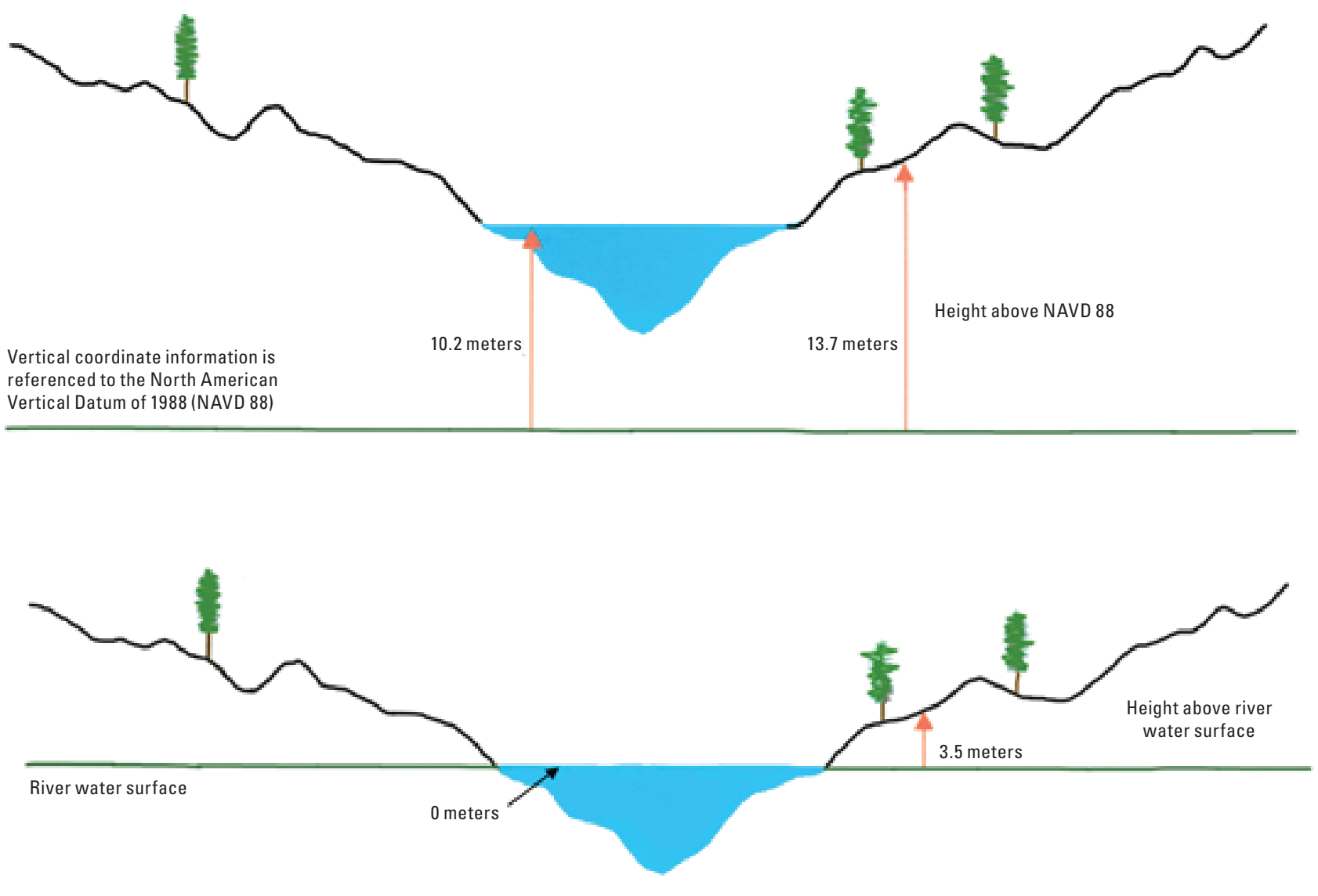

Concept of Relative DEM

Figure 1. The concept of a Relative digital elevation model (DEM).

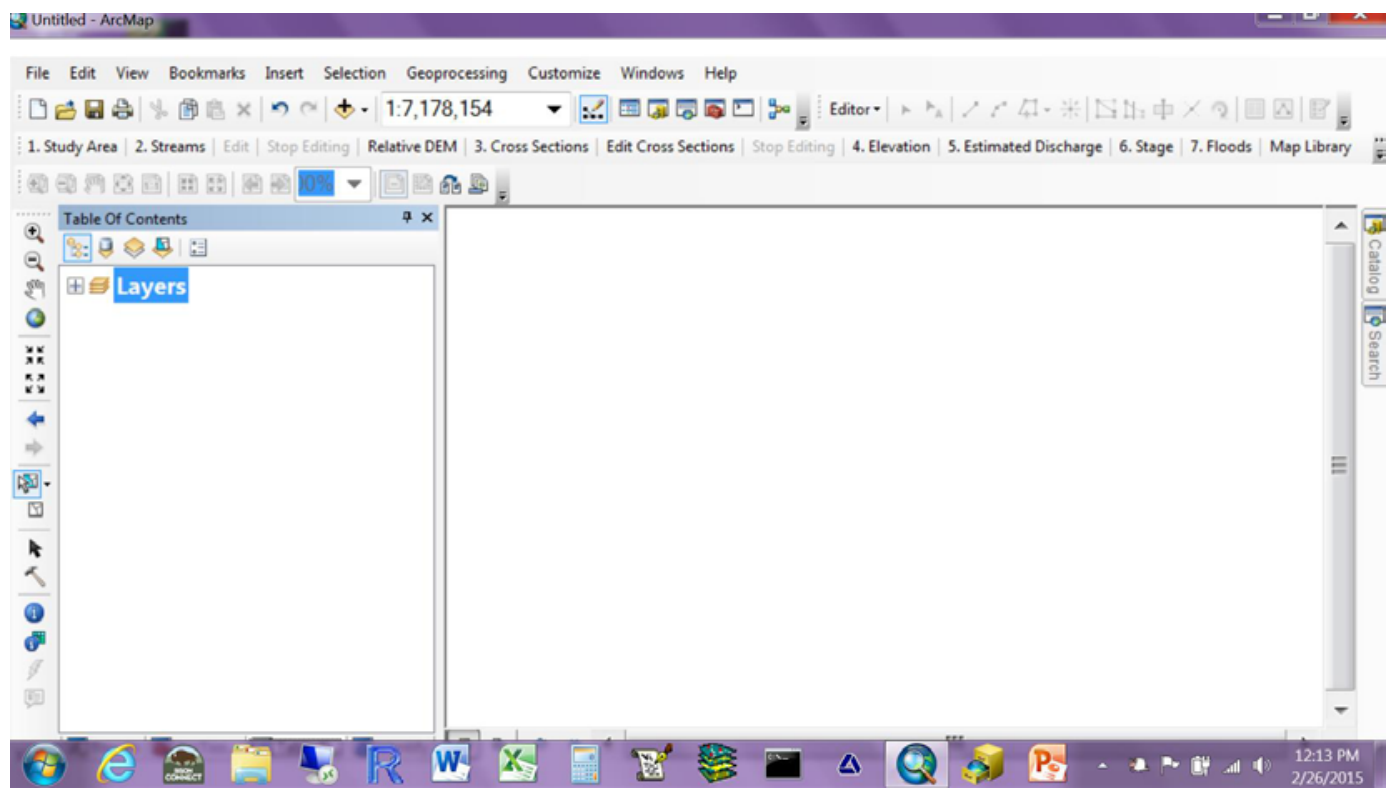

Figure 2. An empty ArcGIS interface with the GIS Flood Tool (GFT). 
1. Define the extent of the study area and specify the required inputs ("Study Area" button) - Four raster datasets are required by the GFT:

- The unconditioned ("raw") DEM for the area,

- The hydrologically conditioned DEM,

- Flow directions derived from the hydrologically conditioned DEM, and

- Flow accumulations derived from the hydrologically conditioned DEM.

2. Create the streams ("Streams" button) - Create streams from the flow accumulation grid by specifying an areal threshold and edit the streams if necessary.

3. Create the Relative DEM ("Relative DEM" button)Create the relative DEM using the hydrologically conditioned DEM and the streams created in step 2.

4. Create cross sections ("Cross Sections" button) - The user specifies the desired width of the cross section and a cross section is automatically placed at the midpoint of every stream reach, orthogonal to the overall trend of the stream reach. The user has the opportunity to edit the placement and rotation of these cross sections.

5. Create the depth-discharge relationship for each reach ("Elevation" button) - This tool develops a depthdischarge relationship for each stream reach using the elevation data from the Relative DEM that underlies each of the cross sections. The elevation data are used to define the wetted perimeter and cross-sectional area needed for the Manning equation. The user has the opportunity to specify a Manning " $n$ " for each reach.

6. Input discharge for a known event ("Estimated Discharge" button) - This button opens a table that the user populates with a discharge value for each stream reach. These discharge values can be measured or modeled, as desired by the user.

7. Evaluate stage for the known event ("Stage" button) Use the depth-discharge curves developed in step 5 to determine the stage associated with the specified discharge for each reach.

8. Create event-specific flood inundation maps ("Floods" button) - Use the relative DEM along with the calculated stage to create inundation patterns for each stream reach for the specified discharge.

9. Create a map library ("Map Library" button) - This tool uses the Relative DEM to create a series of flood inundation maps based on predefined intervals of depth. The extent of inundation is created by querying the Relative DEM for all pixels with values less than or equal to the specified depth above the river. The user can create a map library at any time in the process after creating the Relative DEM.

\section{Elevation Data}

As explained in the "Software Tools" section, the GFT uses a DEM to derive the stream network and to develop cross-sectional information (which is used to build the depthdischarge relationship using the Manning equation). The DEM also provides the basis for mapping the inundation pattern onto the landscape.

The initial GFT was envisioned to work with the quasiglobally available HydroSHEDS dataset (Lehner and others, 2008), which is a hydrologically conditioned version of the void-filled Shuttle Radar Topography Mission (SRTM) 3-arc-second (about $90 \mathrm{~m}$ ) elevation data (Jarvis and others, 2008). The HydroSHEDS dataset hydro-enforced the DEM by using a stream burning algorithm to force agreement between DEM-derived stream lines and stream lines derived from cartographic sources; therefore, although HydroSHEDS provides good stream networks and basin boundaries, the stream burning procedures used to hydro-enforce the dataset made the HydroSHEDS unsuitable for flood inundation mapping. The HydroSHEDS is unsuitable for flood inundation mapping because the stream burning algorithm created substantial trenches along the stream channels, creating unrealistic carrying-capacity of the streams; consequently, a new SRTM for Flood Mapping (SRTM-FM) dataset was developed (Arcorace and others, 2015). The SRTM-FM honors much of the network and basin boundary definition from the HydroSHEDS without extreme stream burning; furthermore, as requested by GFT experimental users, the current (2016) version of the GFT can be used with DEM data of any source or resolution. Therefore, higher resolution, locally produced DEMs can be used with the GFT to obtain more detailed estimates of flood inundation than are possible with the 3 -arc-second SRTM-FM. The quality of the modeled inundation patterns is affected greatly by the vertical and horizontal resolution of the DEM.

\section{Software Validation}

A number of test applications of the GFT were run at many locations within the United States and around the world. In each instance, the purpose was to compare inundation patterns produced by the GFT with independent results obtained by other methods and/or observation with imagery. The locations for application of the GFT within the United States were selected in consultation with the USGS FIM Program. These sites were selected because they had been modeled previously using a one-dimensional hydraulic model and were representative of differing terrains and hydraulic conditions. Unfortunately, outside of the United States, many of the comparisons can only be made qualitatively, since hydraulic studies have not been done. 


\section{Comparisons within the United States}

In cooperation with the USGS FIM Program, the GFT was used to model inundated extents for 11 sites across the eastern United States, and the results were compared with those obtained using one-dimensional hydraulic models. These 11 sites were selected by FIM Program staff to represent a variety of topographic and hydraulic settings and were locations that already had flood inundation map libraries created using one-dimensional hydraulic models (Benedict and others, 2013; Czuba and others, 2014; Flynn and others, 2012; Fowler, 2014; Hoppe and Watson, 2012; Iowa Flood Information System, 2016; Lombard, 2013; Murphy and others, 2012; Roland and Hoffman, 2011; Roland and others, 2014; Storm, 2012). These sites all correspond to National Weather Service (NWS) Flood Forecast points. Inundated extents were developed with the GFT using the same DEM data as were used in the one-dimensional hydraulic modeling studies. These DEM data were quite often the 1/9-arc-second (about $3 \mathrm{~m}$ ) National Elevation Dataset (NED) DEM data (Gesch and others, 2002). The GFT results and the one-dimensional hydraulic model results were compared, wherever possible, for the five NWS categories of inundation level (action, minor flooding, moderate flooding, major flood, and flood of record). The flood inundation patterns available from the FIM Program at the time of the comparison (2013) were used; since that time, more inundation patterns have been developed, but they have not been incorporated into these results. The results are summarized in table 1 and in figures 3 through 13.

The metric used for comparison was the coefficient of areal correspondence (Taylor, 1977). In its application, the inundation patterns from the one-dimensional hydraulic modeling-based studies were taken as baseline for comparison since this method is widely regarded as producing the most accurate modeled flooded area representation. The coefficient was then calculated as simply the area of agreement between the one-dimensional hydraulic model results and GFT results, divided by the combined area of the two methods; in GIS parlance, the intersection of the areas divided by their union. In this way, the success of the GFT is reduced equally by errors of omission and commission. The coefficient of areal correspondence is a conservative metric because, by assuming that the one-dimensional hydraulic models are always correct, cases of the GFT being correct while one-dimensional hydraulic modeling is incorrect are not considered, though undoubtedly there must be some among the many cases tested.

Data in table 1 show that in 39 of 42 cases the coefficient of areal correspondence is 70 percent or higher. Many cases have coefficients better than 80 percent and some have values greater than 90 percent. In 80 percent of the cases, the GFT results agree with at least 75 percent of the one-dimensional hydraulic modeling inundated area.

Special attention should be paid to sites with low relief and subtle surface-water divides. An example of a site with these characteristics is the Leaf River at Hattiesburg, Mississippi (fig. 6). At higher flows, the one-dimensional hydraulic model results (Storm, 2012) show inundated areas in the southwest corner of the study area that extend beyond the subtle surface water divide, but the GFT does not. This difference shows a shortcoming of the GFT because it does not manage such situations. Remedies to this shortcoming are being tested for a future version of the GFT. In the meantime, settings like the Leaf River site, with such low relief and subtle surface water divides, should be avoided. The GFT is best suited to river reaches with well-defined relief and separation from adjacent basins.

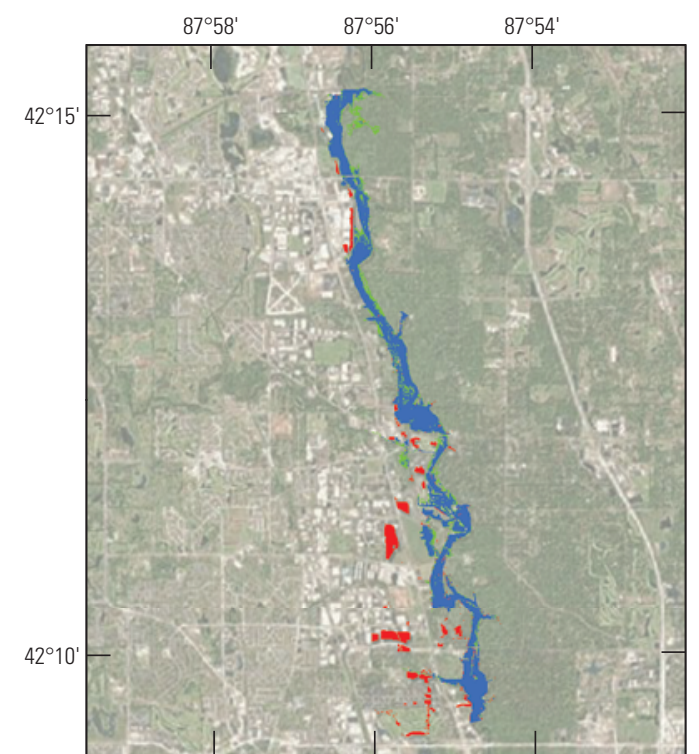

Base from Esri and Digital Globe digital data

State Plane, Illinois, FIPS 1201

Transverse Mercator projection

North American Datum of 1983 (NAD 83)

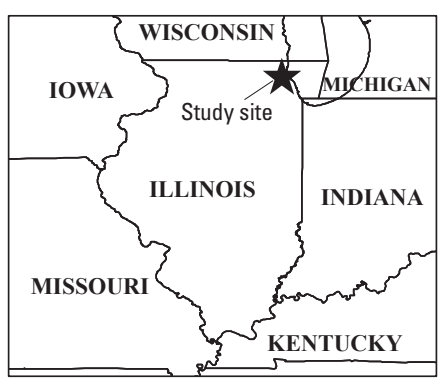

\section{EXPLANATION}

Error of inclusion

Error of exclusion

Agreement

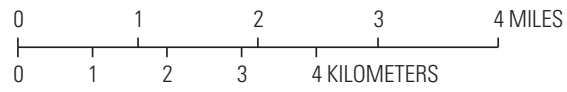

Figure 3. A comparison of the results of the GIS Flood Tool (GFT) and one-dimensional hydraulic modeling for Des Plaines River at Lincolnshire, Illinois (Murphy and others, 2012). 
Table 1. U.S. Geological Survey gaging station names, location, information, and areal correspondence between GIS Flood Tool (GFT) and one-dimensional hydraulic modeling for 11 sites.

[USGS, U.S. Geological Survey; NWS, National Weather Service; ID, identification; DEM, digital elevation model; NED, National Elevation Dataset; --, not applicable; lidar, light detection and ranging]

\begin{tabular}{|c|c|c|c|c|c|c|c|c|c|c|c|}
\hline \multirow[b]{2}{*}{ Location } & \multirow{2}{*}{$\begin{array}{c}\text { USGS } \\
\text { gage } \\
\text { number }\end{array}$} & \multirow{2}{*}{$\begin{array}{c}\text { NWS } \\
\text { site } \\
\text { ID }\end{array}$} & \multirow[b]{2}{*}{ DEM source } & \multirow[b]{2}{*}{ Cell size } & \multicolumn{5}{|c|}{ Coefficient of area correspondence, in percent (Taylor, 1977) } & \multirow{2}{*}{ Figure } & \multirow[b]{2}{*}{ Reference } \\
\hline & & & & & $\begin{array}{c}\text { Action } \\
\text { level }\end{array}$ & $\begin{array}{c}\text { Minor } \\
\text { flooding }\end{array}$ & $\begin{array}{l}\text { Moderate } \\
\text { flooding }\end{array}$ & $\begin{array}{l}\text { Major } \\
\text { flooding }\end{array}$ & $\begin{array}{l}\text { Flood of } \\
\text { record }\end{array}$ & & \\
\hline Des Plaines River at Lincolnshire, Illinois & 5528100 & LDRI2 & 1/9-arc-second NED & $1 / 9$ arc-second & -- & -- & 68.60 & -- & -- & 3 & Murphy and others, 2012. \\
\hline East Fork White River near Bedford, Indiana & 3371500 & BFRI3 & 1/9-arc-second NED & 1/9 arc-second & -- & 57.70 & 88.90 & 91.90 & 92.80 & 4 & Fowler, 2014. \\
\hline Iowa River at Iowa City, Iowa & 5454500 & IOWI4 & 1/9-arc-second NED & 5 meters & 83.00 & 79.20 & 78.80 & 74.90 & 80.90 & 5 & $\begin{array}{l}\text { Iowa Flood Information } \\
\text { System, } 2016 .\end{array}$ \\
\hline Leaf River at Hattiesburg, Mississippi & 2473000 & HATM6 & 1/9-arc-second NED & 5 meters & -- & 74.20 & 78.80 & 72.80 & 75.90 & 6 & Storm, 2012. \\
\hline Mississippi River at St. Paul, Minnesota & 5331000 & STPM5 & Lidar & 3 feet & 88.40 & 88.10 & 88.00 & 76.90 & 82.60 & 7 & Czuba and others, 2014. \\
\hline Saddle River at Lodi, New Jersey & 1391500 & LODN4 & 1/9-arc-second NED & 5 meters & -- & 76.70 & 74.40 & 78.10 & 64.50 & 8 & Hoppe and Watson, 2012. \\
\hline Saluda River at Greenville, South Carolina & 2162500 & GSLS1 & 1/3-arc-second NED & $1 / 3$ arc-second & 72.90 & -- & 79.50 & 83.70 & 90.50 & 9 & Benedict and others, 2013. \\
\hline $\begin{array}{l}\text { Suncook River at North Chichester, New } \\
\text { Hampshire }\end{array}$ & 1089500 & NCHN3 & 1/3-arc-second NED & $1 / 3$ arc-second & -- & -- & -- & 76.30 & -- & 10 & Flynn and others, 2012. \\
\hline Susquehanna River at Harrisburg, Pennsylvania & 1570500 & HARP1 & Lidar & 3.2 -feet & 81.80 & 92.90 & 92.90 & 91.20 & 88.50 & 11 & Roland and others, 2014. \\
\hline Wabash River at Terre Haute, Indiana & 3341500 & HUFI3 & 1/9-arc-second NED & 1/9 arc-second & 94.90 & 77.40 & 91.40 & 90.70 & -- & 12 & Lombard, 2013. \\
\hline $\begin{array}{l}\text { West Branch Susquehanna River at Jersey Shore, } \\
\text { Pennsylvania }\end{array}$ & 1549760 & JRSP1 & 1/9-arc-second NED & 5 meters & 83.70 & 92.70 & 92.10 & 88.40 & 94.50 & 13 & Roland and Hoffman, 2011 \\
\hline
\end{tabular}




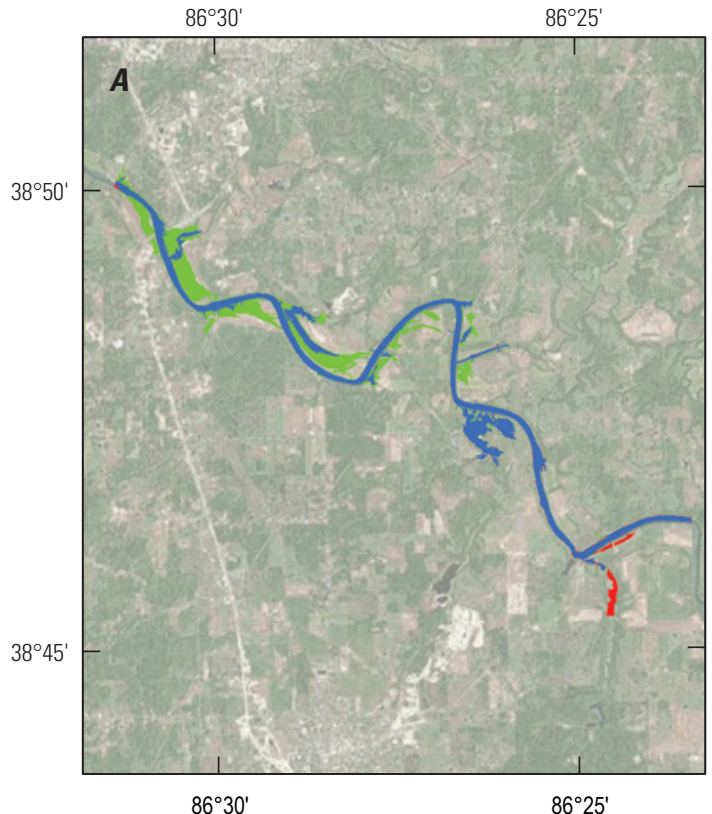

$86^{\circ} 30^{\prime}$

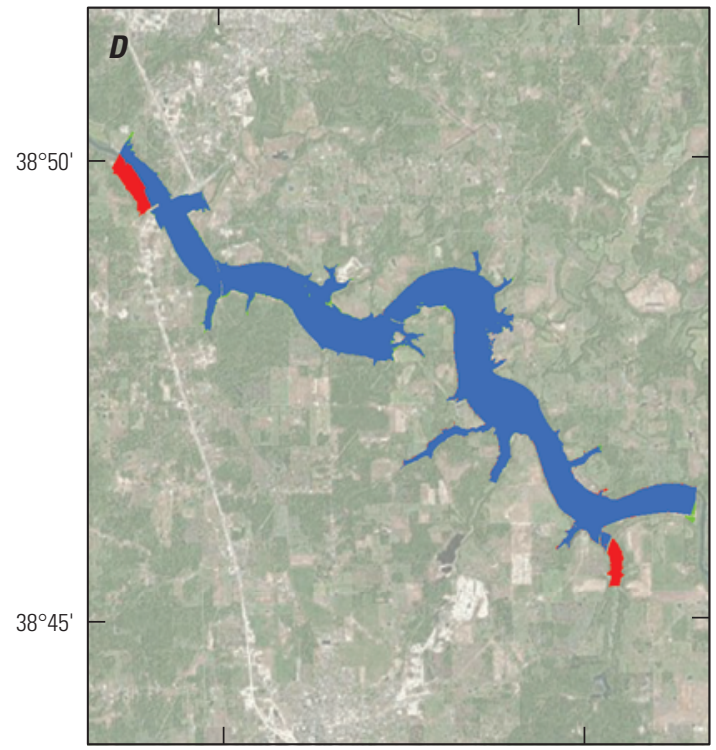

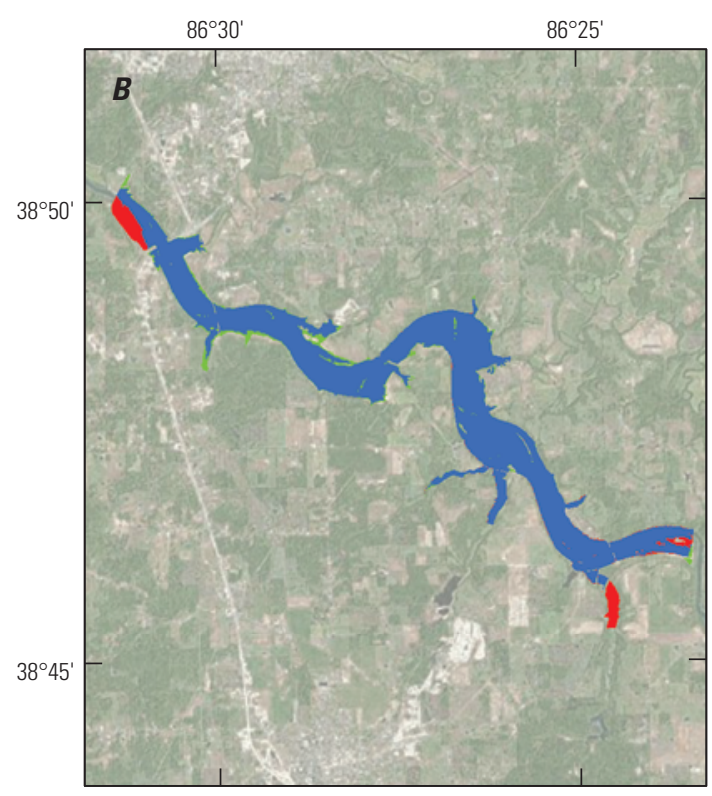

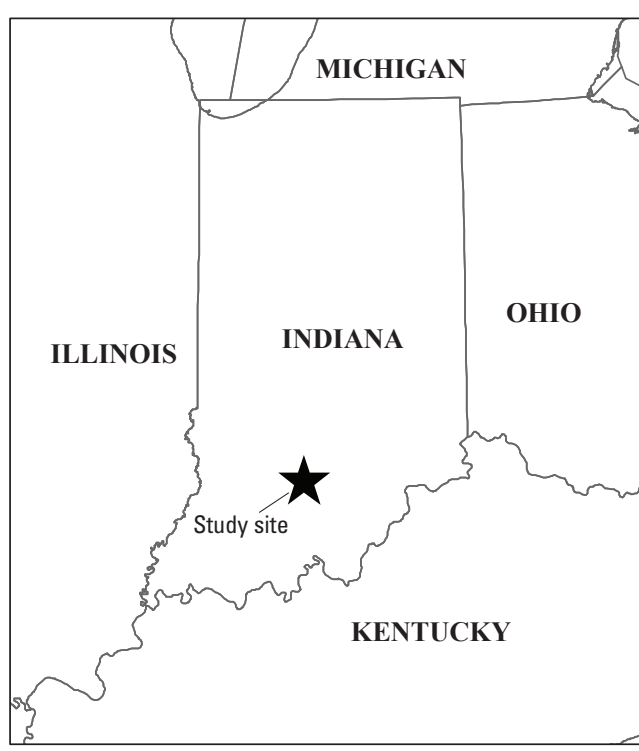

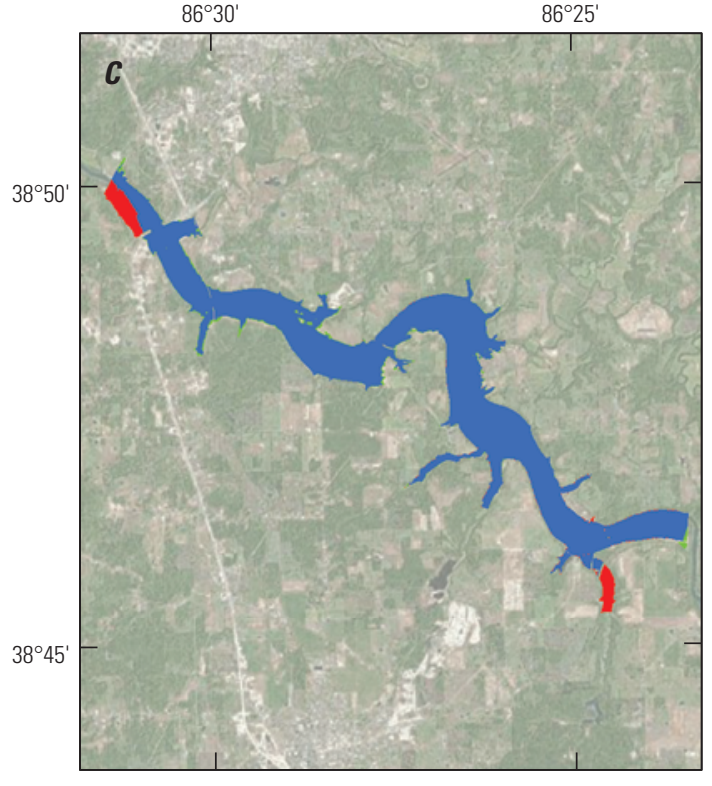

Base from Esri and Digital Globe digital data State Plane, Indiana, FIPS 1302

North American Datum of 1983 (NAD 83)

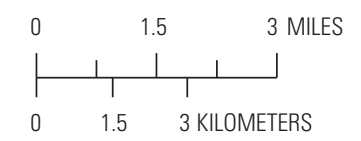

\section{EXPLANATION}

Error of inclusion

Error of exclusion

Agreement

Figure 4. A comparison of the results of the GIS Flood Tool (GFT) and one-dimensional hydraulic modeling for East Fork White River near Bedford, Indiana (Fowler, 2014). $A$, Minor stage of 20.0 feet. $B$, Moderate stage of 30.0 feet. $C$, Major stage of 35.0 feet. $D$, Record stage of 39.0 feet. 

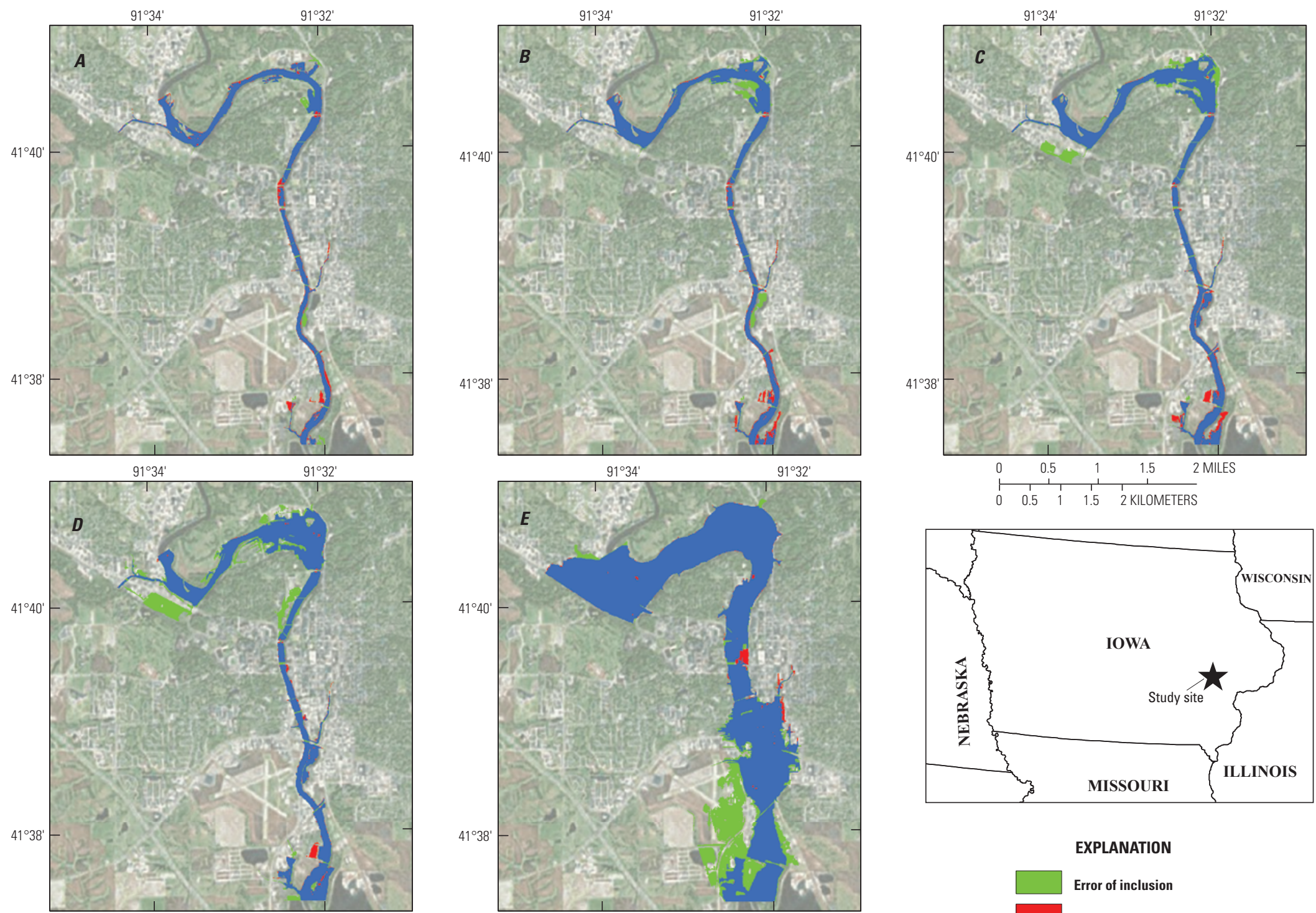

\section{EXPLANATION}

Error of inclusion

Error of exclusion

Base from Esri and Digital Globe digital data

Universal Transverse Mercator projection, Zone $15 \mathrm{~N}$

North American Datum of 1983 (NAD 83)

Agreement

Figure 5. A comparison of the results of the GIS Flood Tool (GFT) and one-dimensional hydraulic modeling for lowa River at lowa City, lowa (lowa Flood Information System, 2016). A, Action stage of 12,300 cubic feet per second ( $\left.\mathrm{ft}^{3} / \mathrm{s}\right)$. B, Minor stage of 13,800 ft3/s. C, Moderate stage of 15,600 ft's.s. D, Major stage of 20,100 ft3/s. E, Record stage of $50,600 \mathrm{ft}^{3} / \mathrm{s}$. 

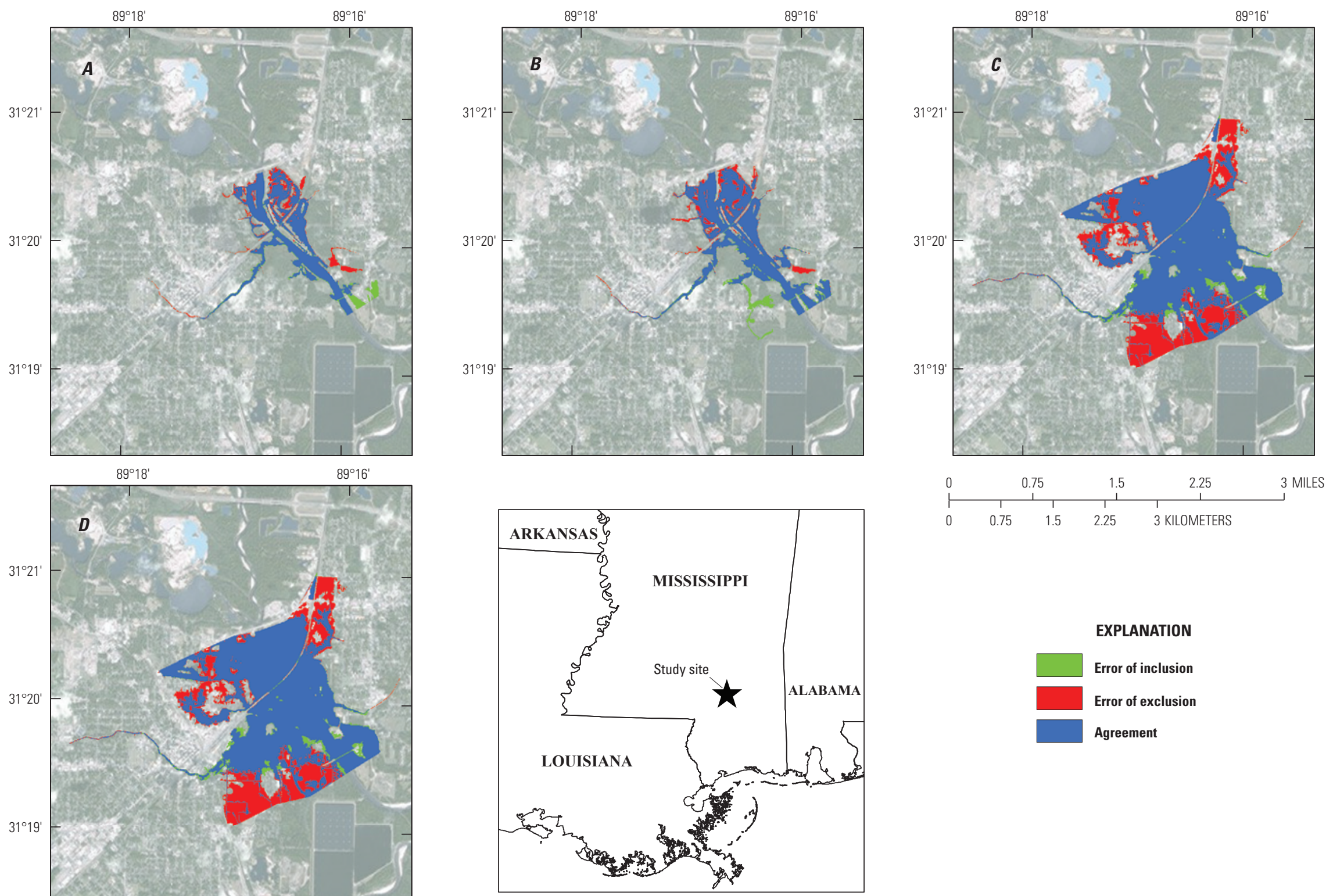

Figure 6. A comparison of the results of the GIS Flood Tool (GFT) and one-dimensional hydraulic modeling for Leaf River at Hattiesburg, Mississippi (Storm, 2012). A, Minor stage of 35,300 cubic feet per second ( $\left.\mathrm{ft}^{3} / \mathrm{s}\right)$. B, Moderate stage of 42,100 ft³/s. C, Major stage of 70,750 ft3 $/ \mathrm{s}$. D, Record stage of $87,170 \mathrm{ft}^{3} / \mathrm{s}$. 

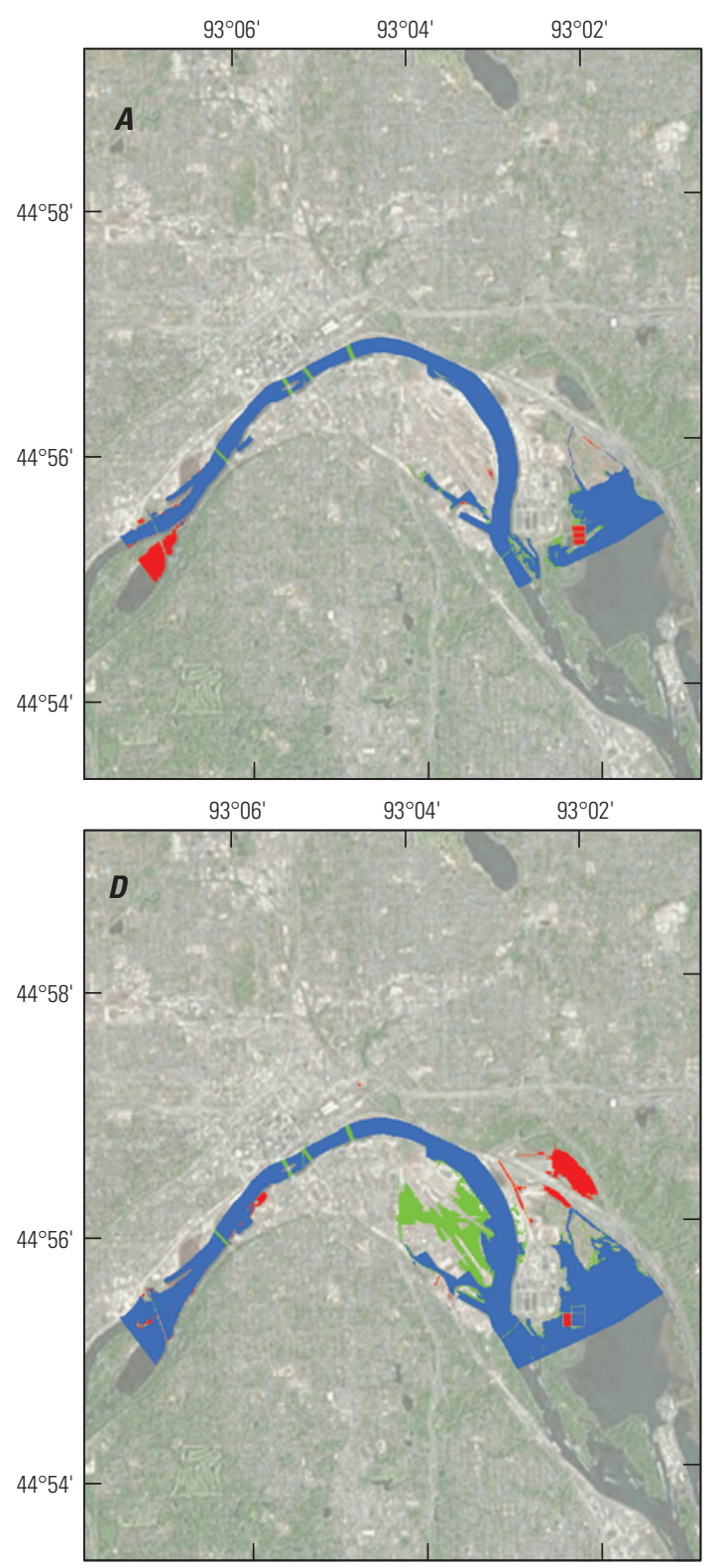

Base from Esri and Digital Globe digital data

Albers Equal-Area Conic projection

North American Datum of 1983 (NAD 83)
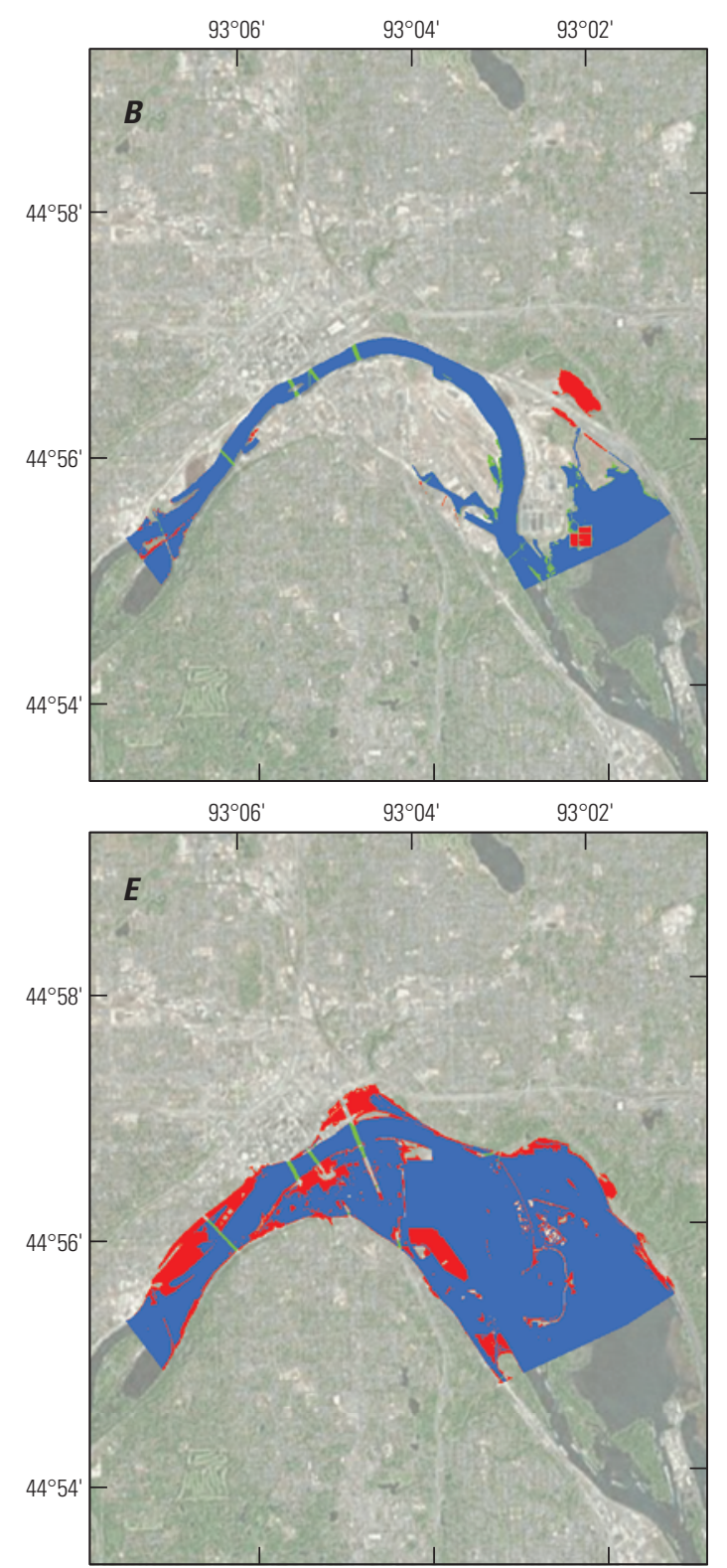

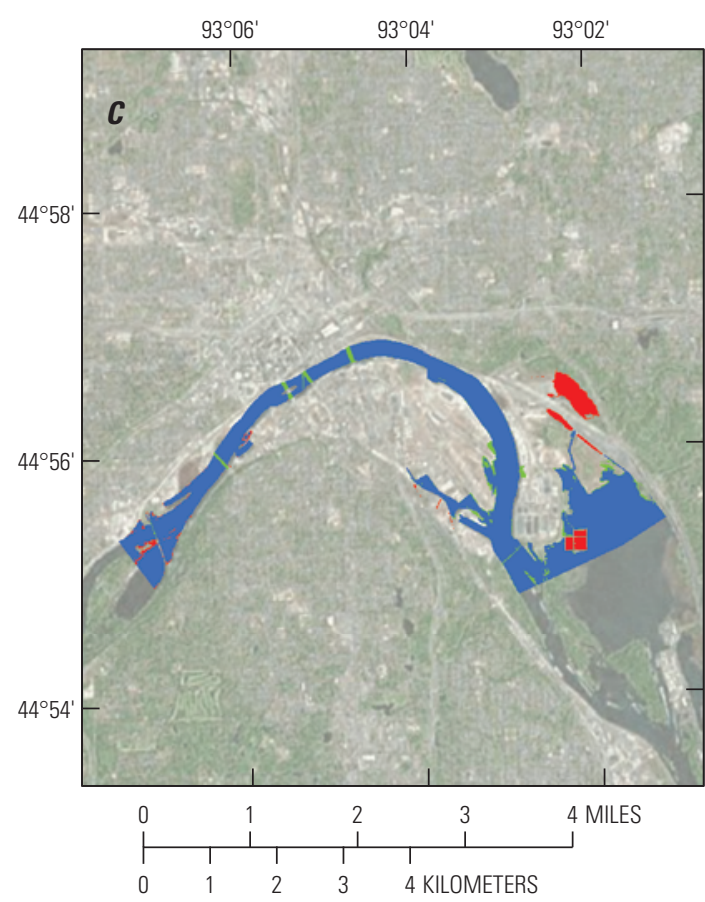

$\overrightarrow{0}$

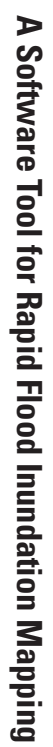

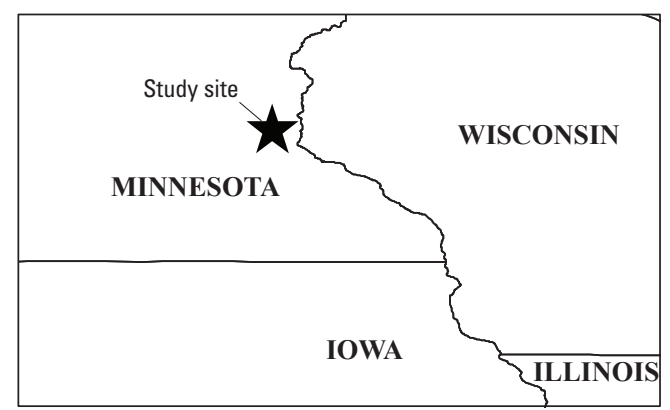

EXPLANATION

\section{Error of inclusion}

Error of exclusion

Agreement

Figure 7. A comparison of the results of the GIS Flood Tool (GFT) and one-dimensional hydraulic modeling for Mississippi River near St. Paul, Minnesota (Czuba and others, 2014). $A$, Action stage of 10.0 feet. $B$, Minor stage of 14.0 feet. $C$, Moderate stage of 15.0 feet. $D$, Major stage of 17.0 feet. $E$, Record stage of 33 feet. 

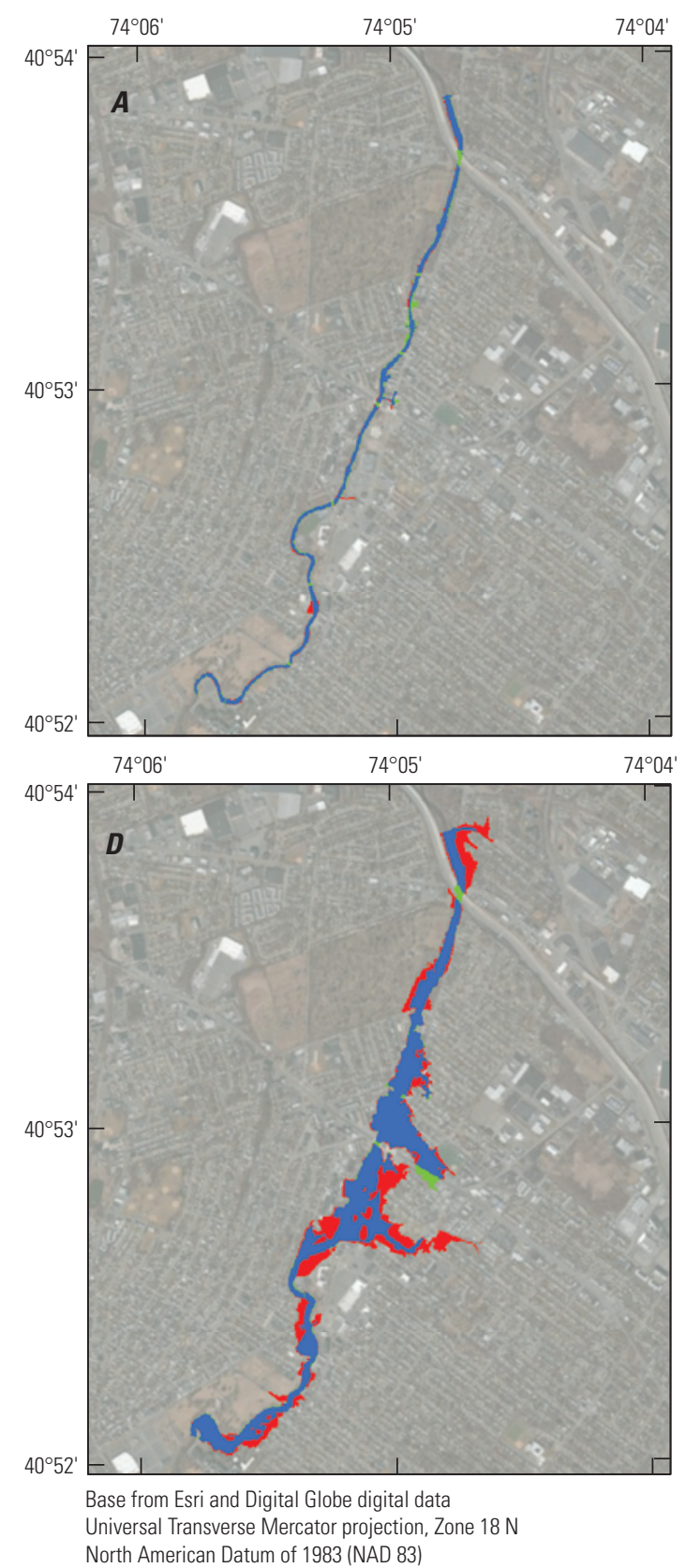
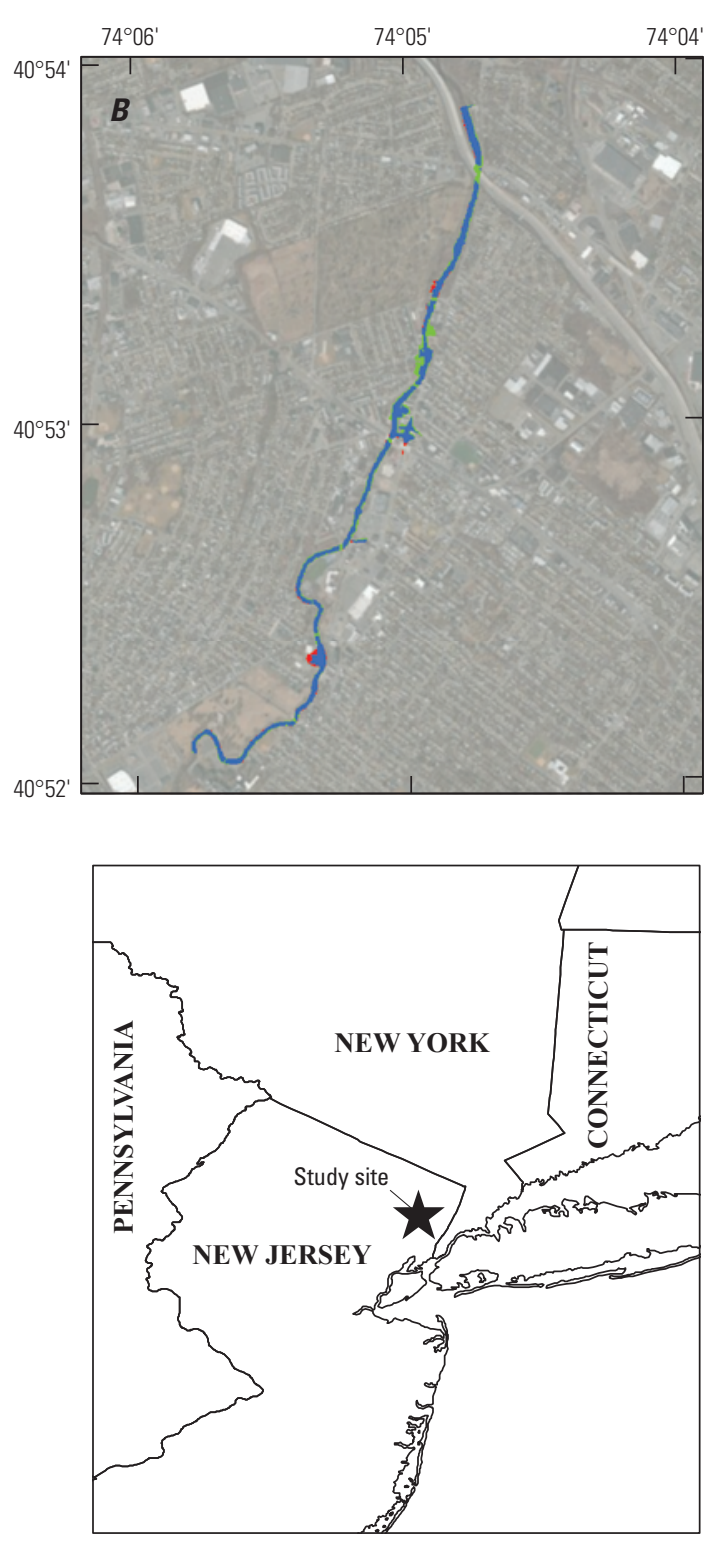

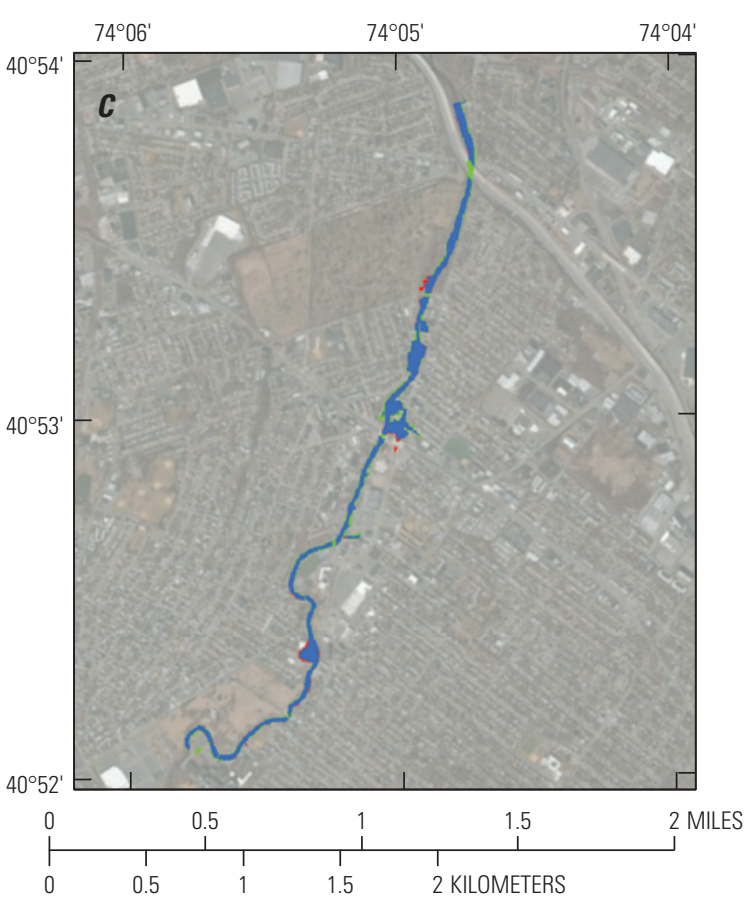

EXPLANATION

Error of inclusion

Error of exclusion

Agreement

Figure 8. A comparison of the results of the GIS Flood Tool (GFT) and one-dimensional hydraulic modeling for Saddle River at Lodi, New Jersey (Hoppe and Watson, 2012). $A$, Minor stage of 1,900 cubic feet per second ( $\left.\mathrm{ft}^{3} / \mathrm{s}\right)$. $B$, Moderate stage of 2,360 $\mathrm{ft}^{3} / \mathrm{s}$. C, Major stage of $3,800 \mathrm{ft}^{3} / \mathrm{s}$. $D, R e c o r d ~ s t a g e ~ o f ~ 6,030 \mathrm{ft}^{3} / \mathrm{s}$. 


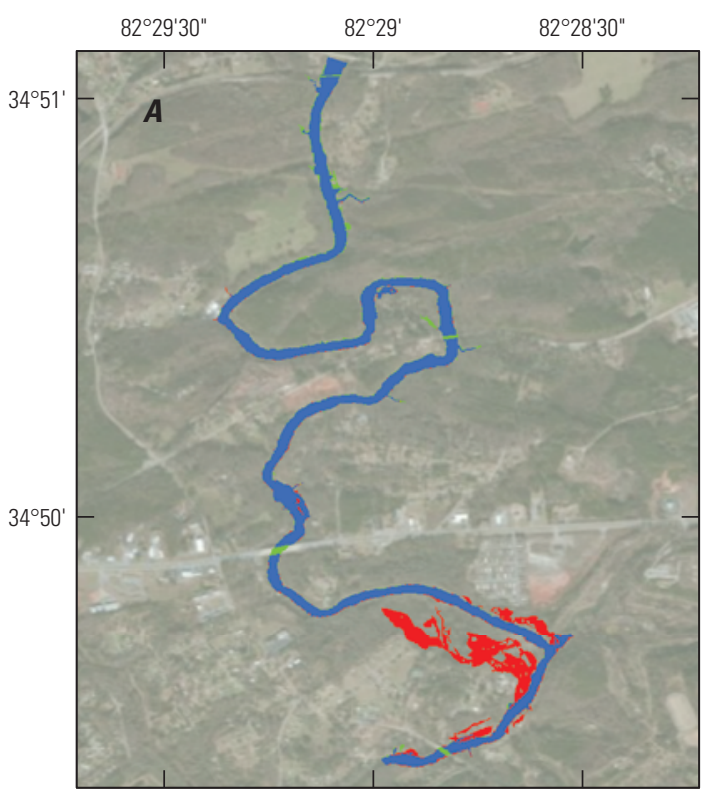

$82^{\circ} 29^{\prime} 30^{\prime \prime}$

$82^{\circ} 29$

$82^{\circ} 28^{\prime} 30^{\prime \prime}$

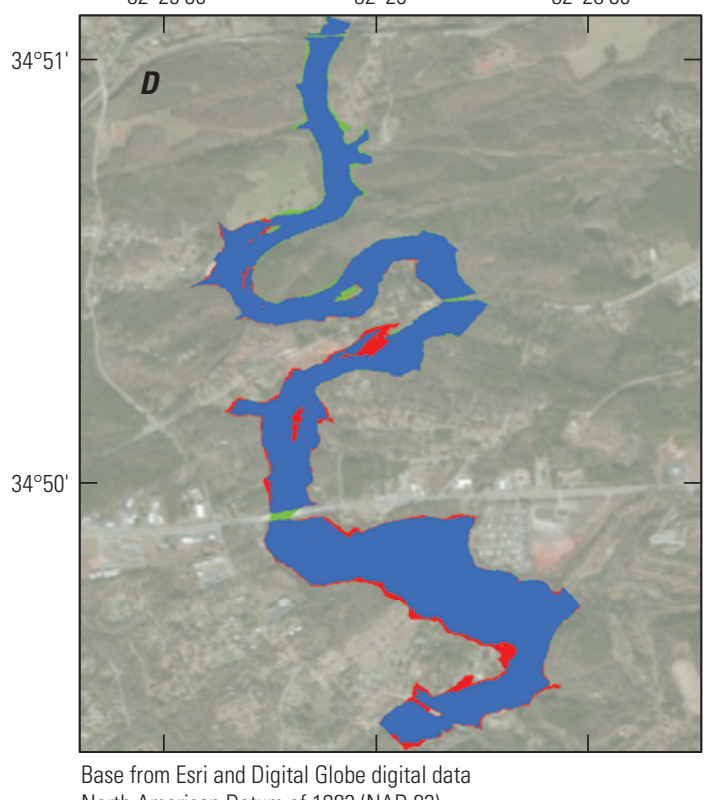

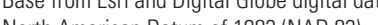

Figure 9. A comparison of the results of the GIS Flood Tool (GFT) and one-dimensional hydraulic modeling for Saluda River at Greenville, South Carolina (Benedict and others, 2013). A, Action stage of 8 feet. $B$, Moderate stage of 13 feet. $C$, Major stage of 15 feet. $D$, Record stage of 20 feet.

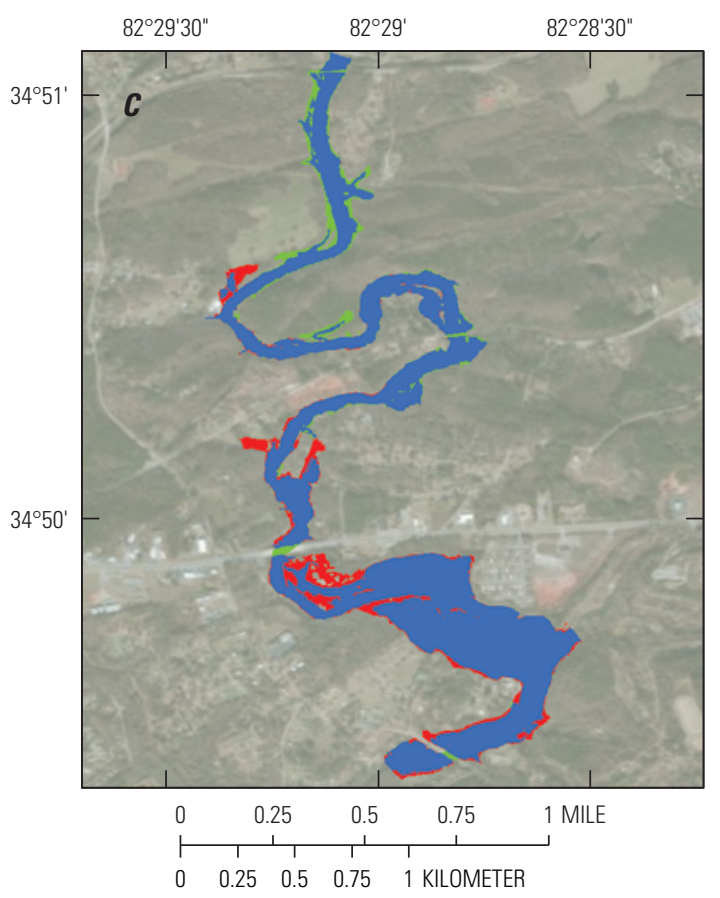

$\overrightarrow{\mathbf{N}}$
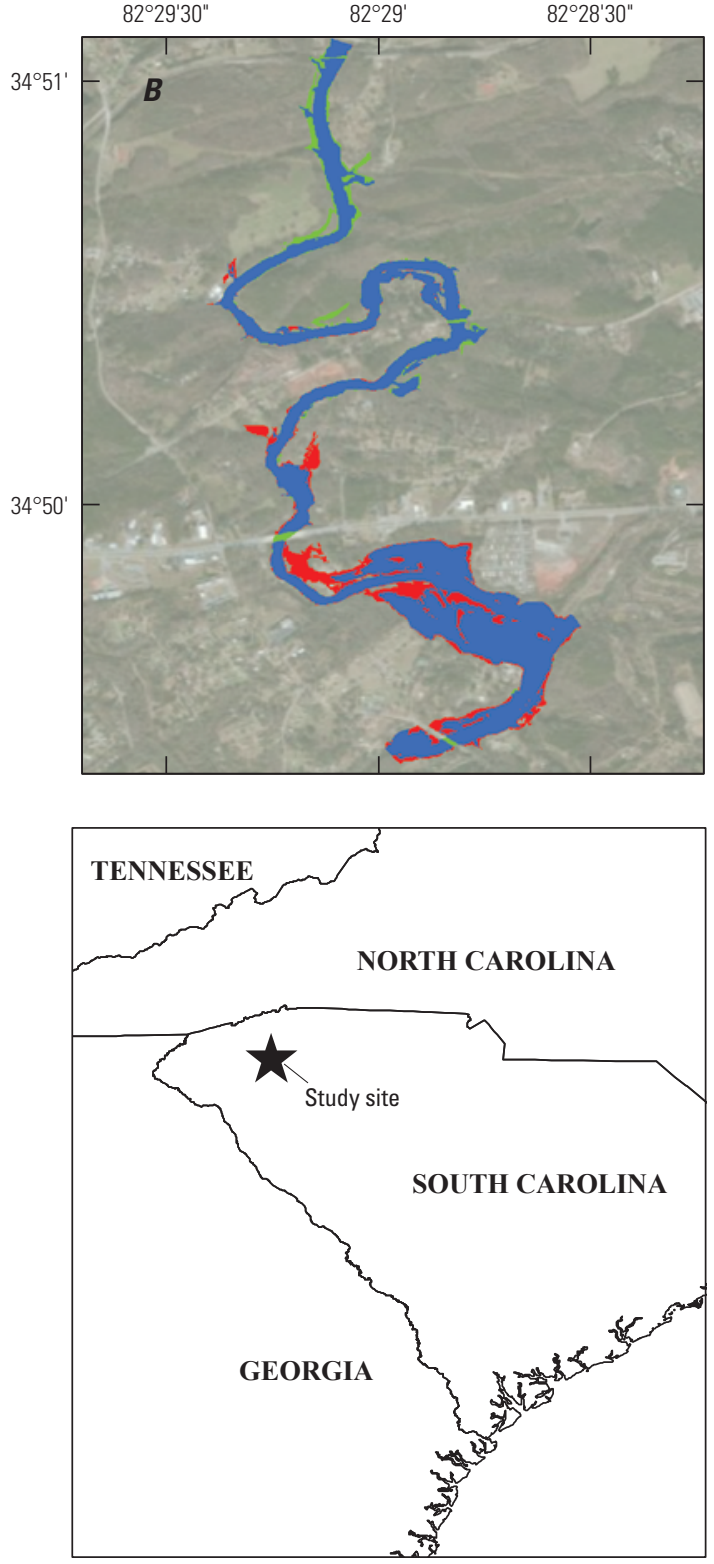

EXPLANATION

Error of inclusion

Error of exclusion

Agreement 


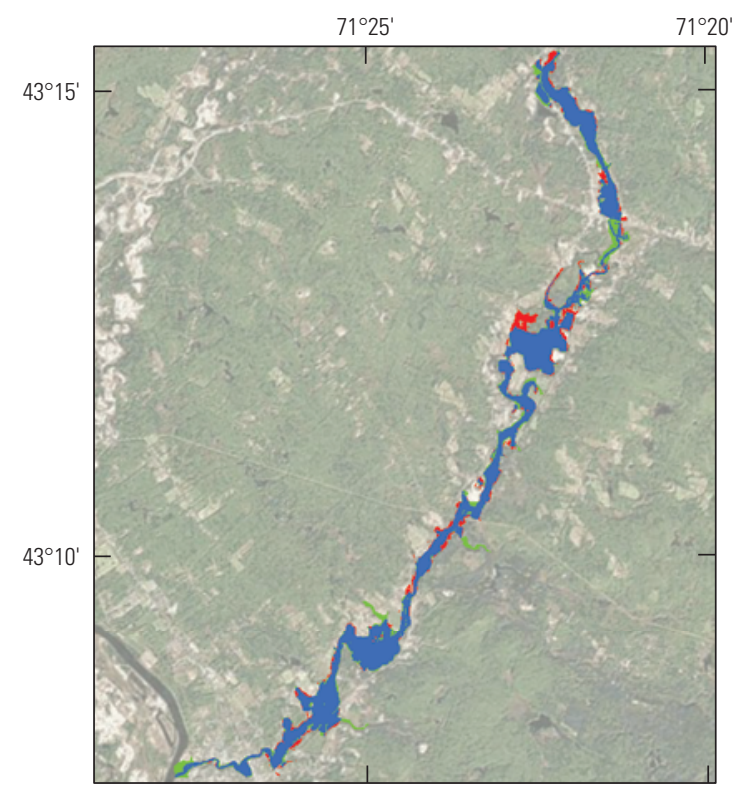

Base from Esri and Digital Globe digital data

State Plane, New Hampshire, FIPS 2800

Transverse Mercator projection

North American Datum of 1983 (NAD 83)

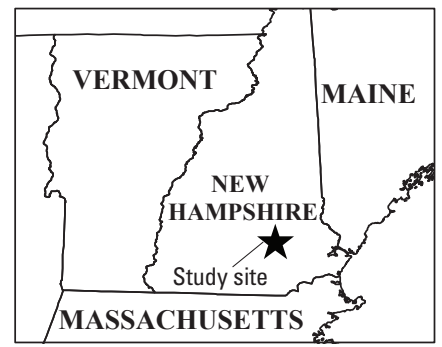

Figure 10. A comparison of the results of the GIS Flood Tool (GFT) and one-dimensional hydraulic modeling for Suncook River at North Chichester, New Hampshire (Flynn and others, 2012). The inundation patterns are shown for the National Weather Service major stage level of 14.0 feet.

\section{Comparisons Outside of the United States}

\section{Okavango River near Rundu, Namibia}

The FEWS NET regional scientist for Southern Africa provided streamflow data and corresponding observed inundation patterns for a flood event in Namibia that were used to check the accuracy of GFT inundation extents.

Data were provided for a flooding event on the Okavango River in March 2009, when heavy rains fell in Angola, northern Namibia, and parts of Zambia's Western Province. The GFT modeled results were compared with inundation patterns extracted from TerraSAR-X satellite radar observations acquired on March 3, 2009, when a discharge of 843.6 cubic meters per second $\left(\mathrm{m}^{3} / \mathrm{s}\right)$ was recorded. This flow value was specified as input to the GFT. The DEM used was the SRTM-FM. The GFT inundation patterns were similar to those obtained from the TerraSAR$\mathrm{X}$ satellite radar observation; however, a quantitative comparison cannot be done.

\section{Blue Nile River in Sudan}

The GFT was tested by Riverside Technology, Inc. (RTi) on the upper Blue Nile River in Sudan from Roseires Reservoir downstream to the confluence with the Dinder River, near Wad Madani.

RTi had previously mapped inundation for the 100 year flood $\left(12,386 \mathrm{~m}^{3} / \mathrm{s}\right)$ using conventional methods using the Hydrologic Engineering Center-River Analysis System (HEC-RAS) from the U.S. Army Corps of Engineers (U.S. Army Corps of Engineers, 2010) and field surveyed cross sections. RTi also developed a 20-meter DEM along the river, and integrated it with the void-filled 90-meter SRTM (Jarvis and others, 2008). The GFT was applied to the 20-meter DEM developed by RTi.

The GFT was run using $12,386 \mathrm{~m}^{3} / \mathrm{s}$ as the specified discharge, mapping inundation onto the RTi 20-meter DEM. The 400-kilometer-long study area was divided into eight reaches within the GFT. The RTi and GFT inundation patterns are compared in figures 15 and 16 . The agreement is very good in the southern one-half of the study area, whereas there are inconsistencies in the northern one-half. The channel is better defined in the south than in the north; the channel in the northern part has flat expanses on the flood plain that can be associated with small differences in inundation depth. These small differences in inundation depth can result in substantial changes in extent of flooding. Nonetheless, the high degree of agreement is remarkable considering the large extent of the study area, the low cost of GFT compared with conventional mapping, and the inherent uncertainties in the inundation patterns produced from a high quality, conventional HEC-RAS approach.

\section{Applications of the GIS Flood Tool Software}

Practical application of the GFT software demonstrates benefit from the investment in development and training. Following are examples of projects that have successfully used the GFT to solve problems that would otherwise have been much more difficult to address. 

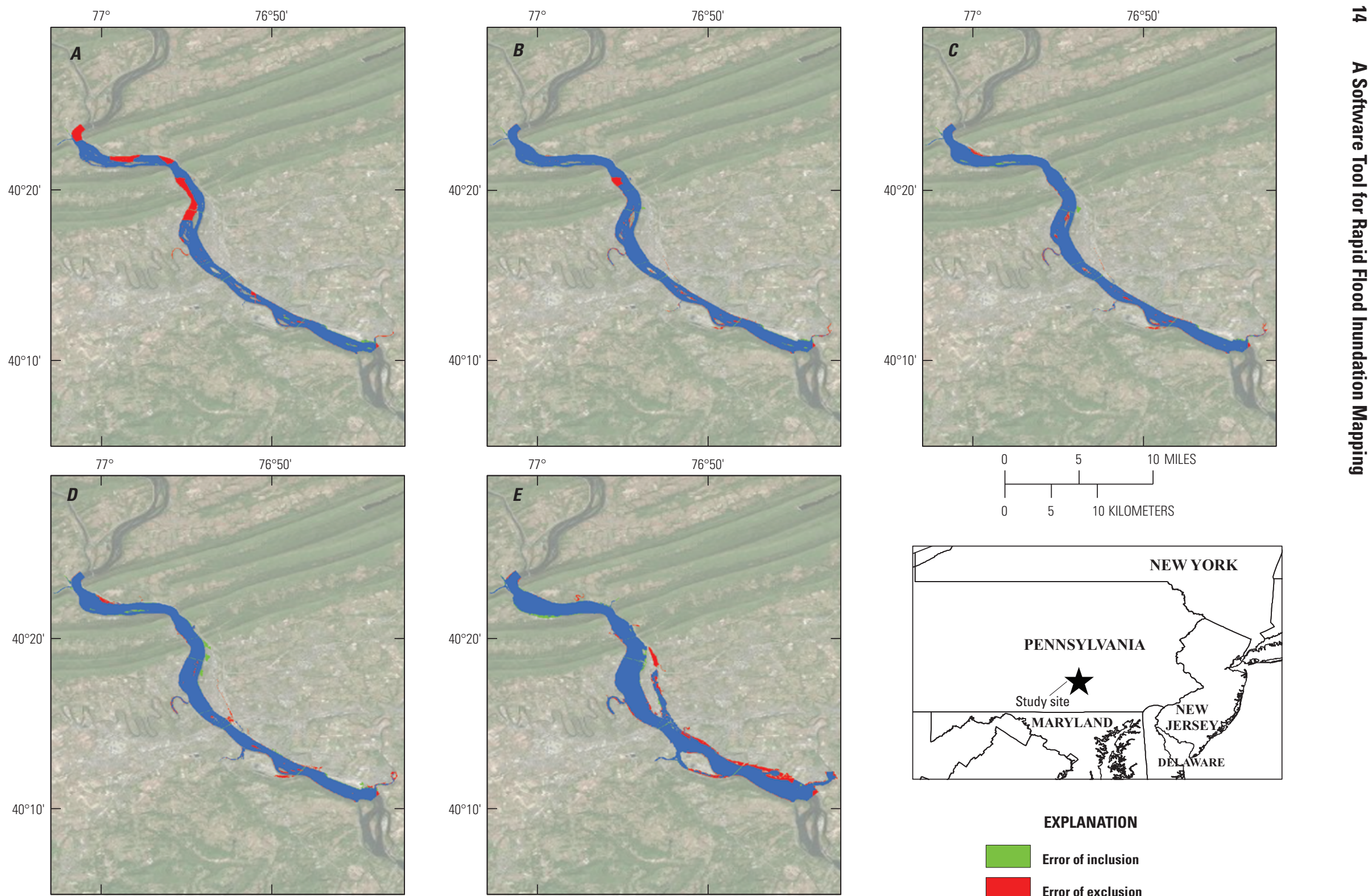
Base from Esri and Digital Globe digital data
North American Datum of 1983 (NAD 83)

Figure 11. A comparison of the results of the GIS Flood Tool (GFT) and one-dimensional hydraulic modeling for Susquehanna River at Harrisburg, Pennsylvania (Roland and others, 2014). A, Action stage of 11.0 feet. $B$, Minor stage of 17.0 feet. $C$, Moderate stage of 20.0 feet. $D$, Major stage of 23.0 feet. $E$, Record stage of 33.3 feet. 

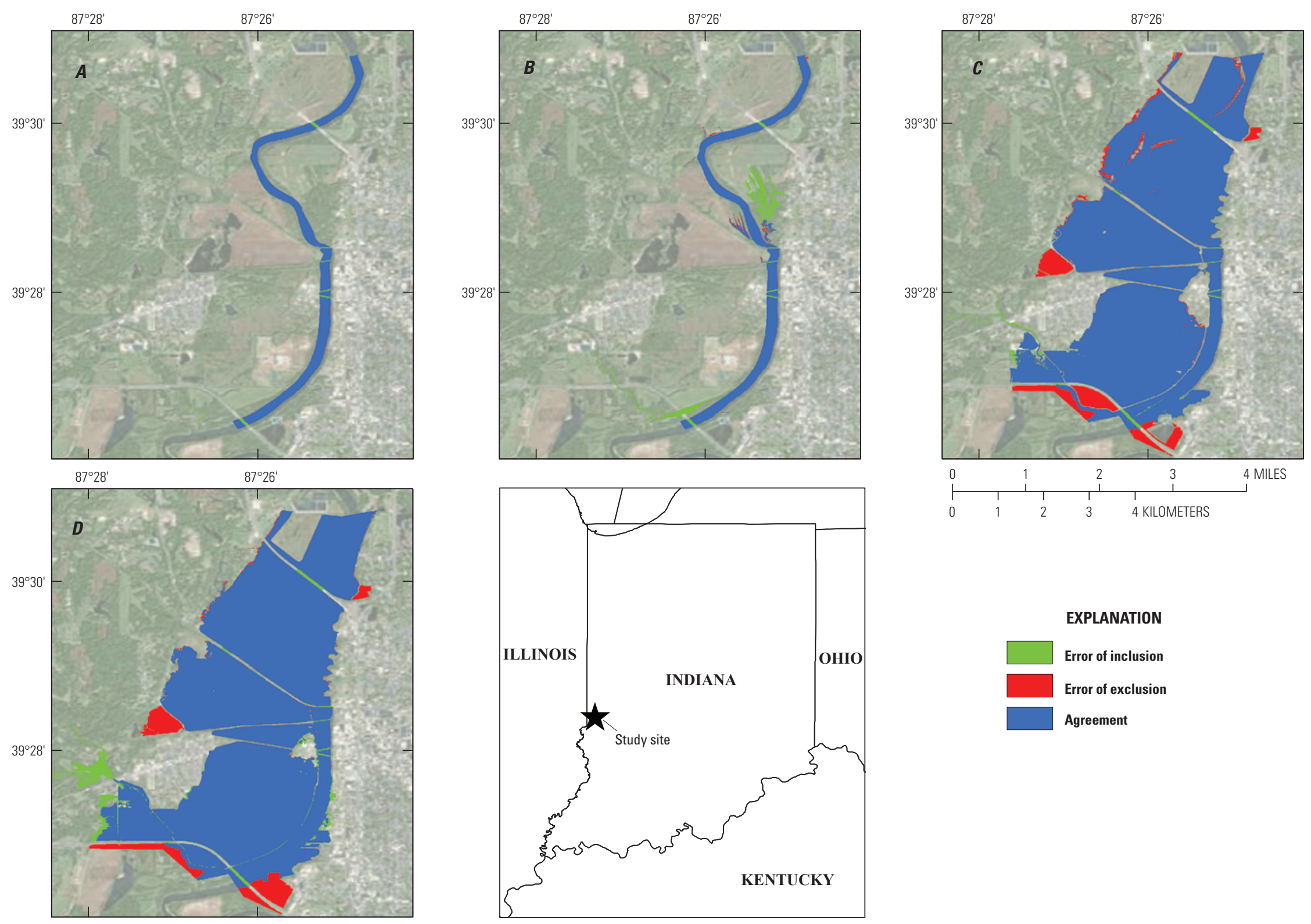

Base from Esri and Digital Globe digital data

Figure 12. A comparison of the results of the GIS Flood Tool (GFT) and one-dimensional hydraulic modeling for Wabash River at Terre Haute, Indiana (Lombard, 2013). $A$, Action stage of 9.0 feet. $B$, Minor stage of 14.0 feet. $C$, Moderate stage of 22.0 feet. $D$, Major stage of 28.0 feet. 

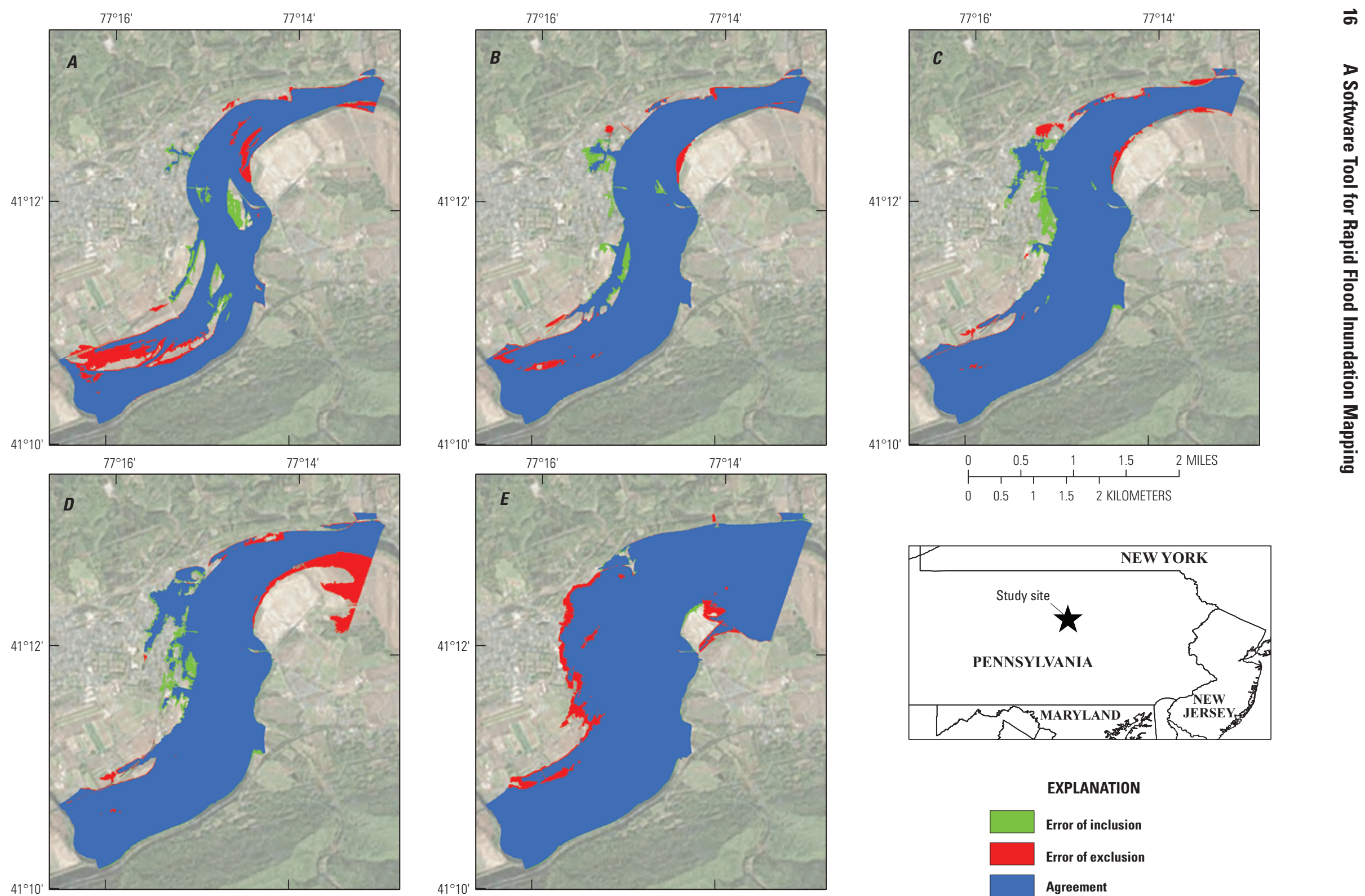

$$
\begin{aligned}
& \text { Base from Esri and Digital Globe digital data } \\
& \text { Universal Transverse Mercator projection, Zone } 18 \mathrm{~N}
\end{aligned}
$$

North American Datum of 1983 (NAD 83)

Figure 13. A comparison of the results of the GIS Flood Tool (GFT) and one-dimensional hydraulic modeling for West Branch Susquehanna River at Jersey Shore,

Pennsylvania (Roland and Hoffman, 2011). A, Action stage of 119,000 cubic feet per second ( $\left.\mathrm{ft}^{3} / \mathrm{s}\right)$. B, Minor stage of 146,000 $\mathrm{ft}^{3} / \mathrm{s}$. C, Moderate stage of $165,000 \mathrm{ft}^{3} / \mathrm{s}$. $D, \mathrm{Major}$ stage of $174,000 \mathrm{ft}^{3} / \mathrm{s}$. $E$, Record stage of $270,000 \mathrm{ft}^{3} / \mathrm{s}$. 

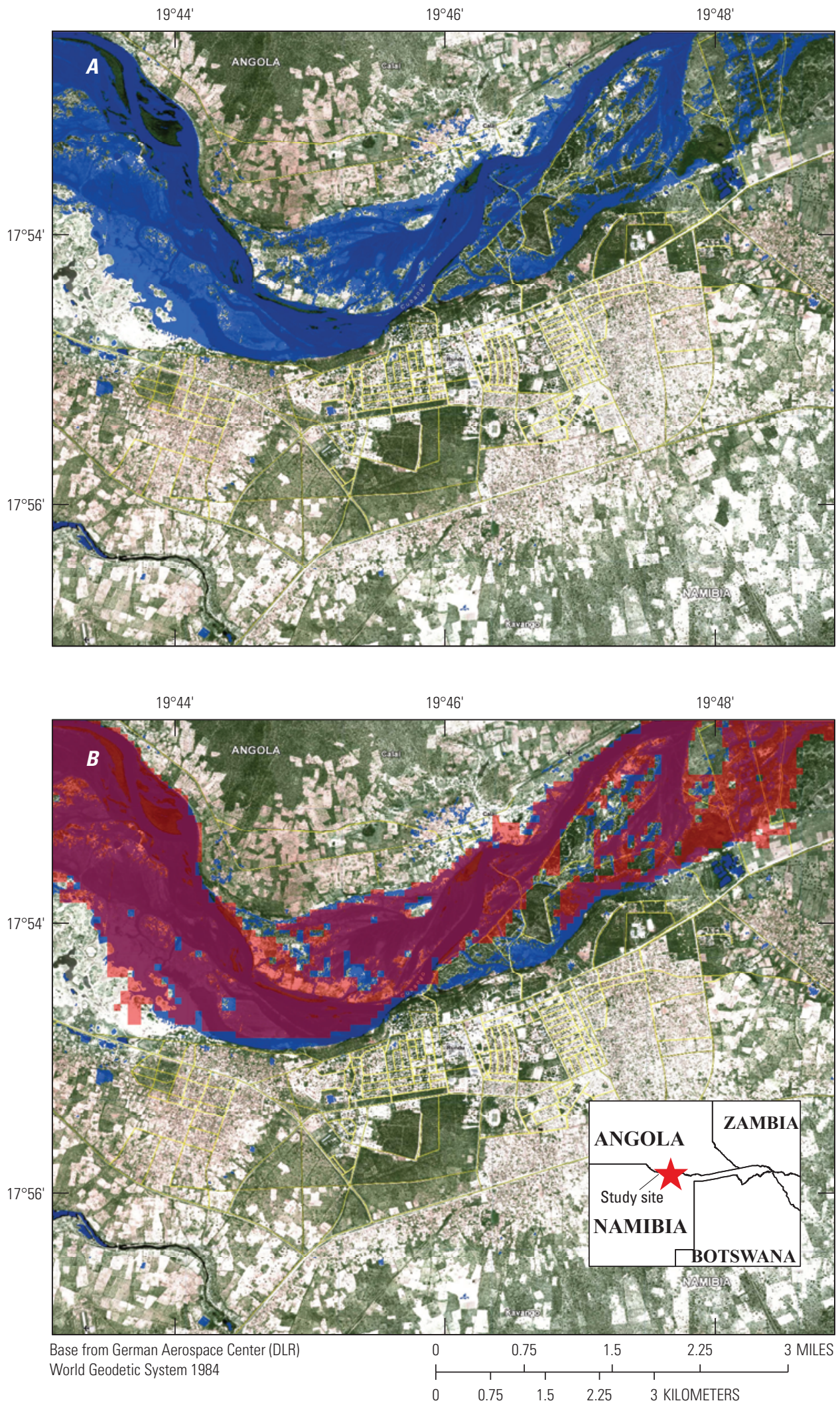

Figure 14. Flooding on the Okavango River near Rundu, Namibia on March 25, 2009.

$A$, observed with TerraSAR-X satellite imagery. $B$, modeled with the GIS Flood Tool (GFT). 


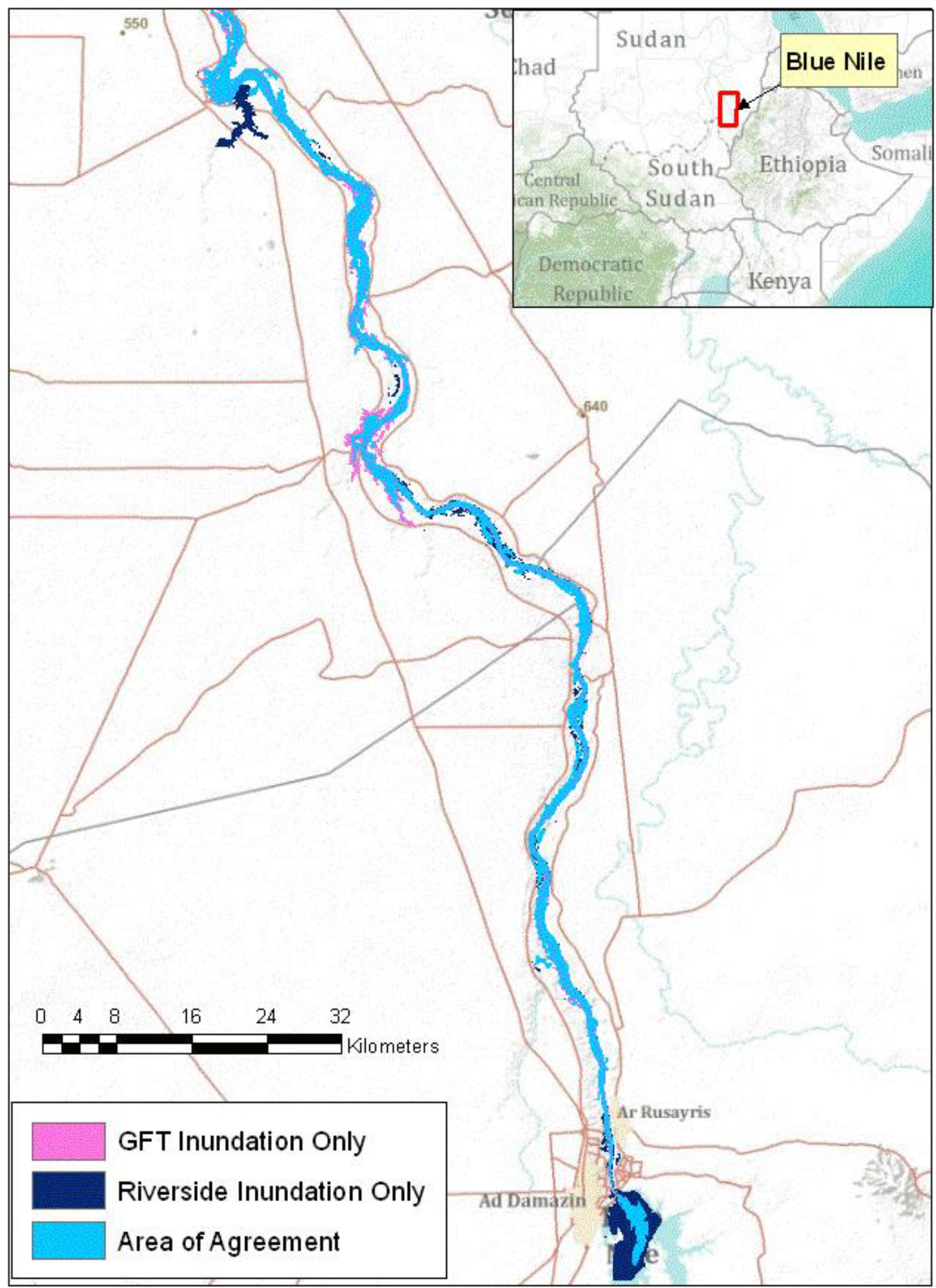

Figure 15. Comparison of GIS Flood Tool (GFT) inundation pattern to patterns from the HEC-RAS study along the southern part of the Blue Nile River in Sudan, East Africa (from Riverside Technology, Inc.). 


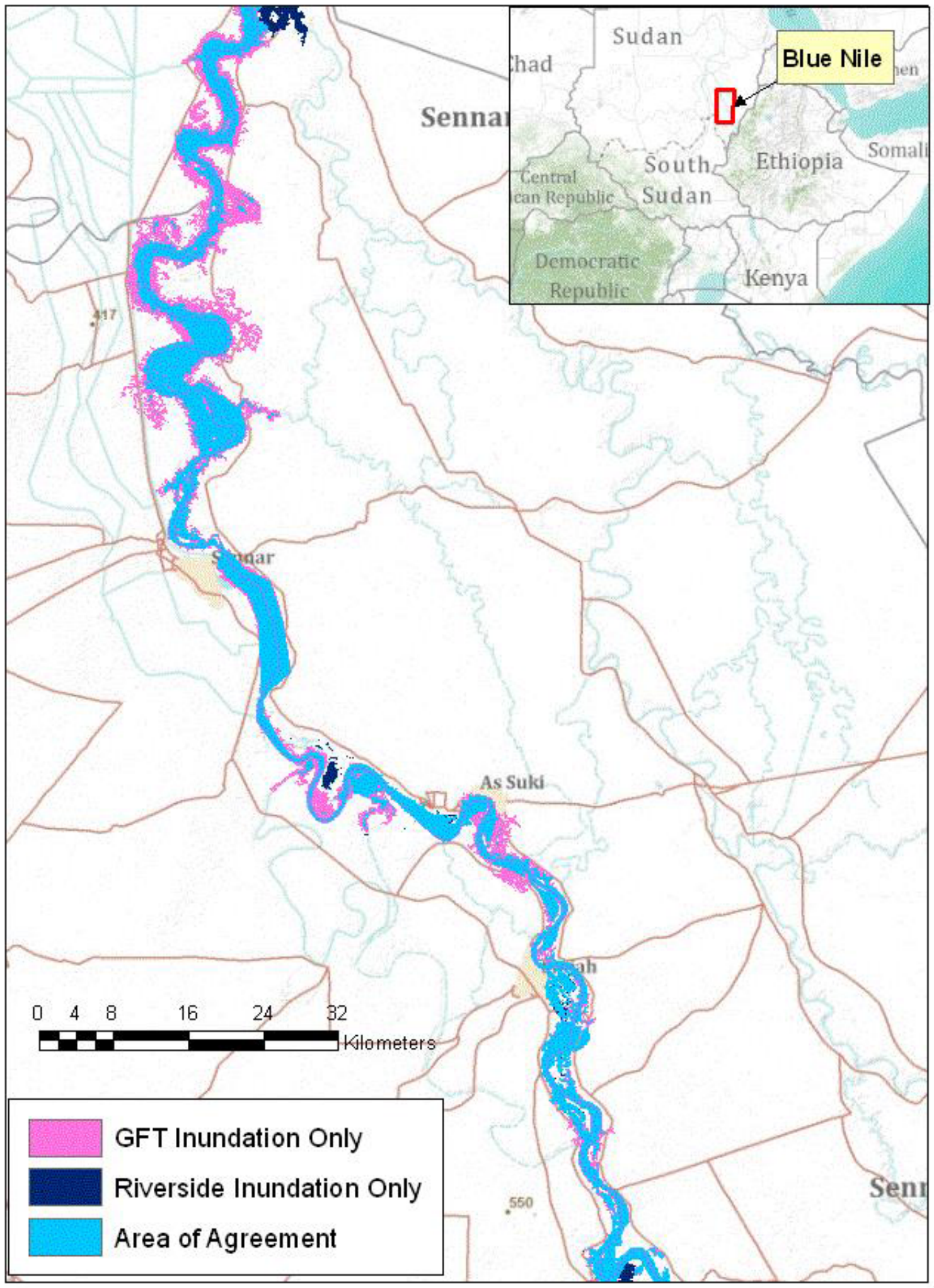

Figure 16. Comparison of GIS Flood Tool (GFT) inundation pattern to patterns from the HEC-RAS study along the northern part of the Blue Nile River in Sudan, East Africa (from Riverside Technology, Inc.). 


\section{Global Assessment Report on Disaster Risk Reduction}

In 2009, the United Nation's International Strategy for Disaster Risk Reduction (UNISDR) issued its "Global Assessment Report on Disaster Risk Reduction" (United Nations Office for Disaster Risk Reduction, 2009). The report provided a worldwide view of the full range of natural disasters and the risks they pose to human populations. The University of Grenoble and United Nations Environment Programme's Global Resource Information Database (UNEP GRID) collaborated with the USGS on their technical approach, and used the Manning equation as implemented within the GFT to generate coarse-scale flood inundation patterns for the continents of the world (Herold and Mouton, 2011). The GFT algorithm has been applied again for the flood chapter of the Global Assessment Report on Disaster Risk Reduction 2015 (http://www.preventionweb.net/english/hyogo/gar/2015/en/ home/GAR_2015/GAR_2015_1.html, accessed June 2015), for which new modeling was completed at the Centro Internazionale in Monitoraggio Ambientale (CIMA) Research Foundation in Italy.

\section{Somalia Water and Land Management Information Management Flood-Risk Maps}

A unit of the Food and Agriculture Organization (FAO) of the United Nations, Somalia Water and Land Management Information Management (SWALIM) has prepared flood inundation map libraries using the GFT for eight priority communities on the Juba and Shabelle Rivers. High-resolution DEM data produced by photogrammetric methods provided the basis for the mapping, along with streamflow records and floodflow frequency analysis. Cartographic products representing the expected flooding for 5-, 50-, and 100-year recurrence intervals are available at the SWALIM Web site at http://www. faoswalim.org/subsites/frrims/methodology.php. An example of these flood-risk maps is presented in figure 17.

\section{Technical Considerations}

\section{Importance of Digital Elevation Model Resolution and Quality}

The resolution and quality of the DEM used as input to the GFT have a major effect on the quality of the resulting inundation maps. The effect of the DEM resolution and quality is evident in the images presented in figures 18 and 19. In figure 18, the GFT software was used with different resolution DEMs by SWALIM staff for a reach along the Juba River in Somalia (10-meter photogrammetric source and 3-arc-second
SRTM-FM). Although there are no definitive verification data available, it is clear from the two figures that the 5-meter DEM gave more clearly defined, detailed, and smooth flood inundation areas, compared to the 90-meter DEM. The extent of the flooded areas is, however, roughly the same for the two DEMS. In figure 19, inundation patterns were generated using the NED 1/9-arc-second and 1/3-arc-second data as well as the SRTM-FM for the West Branch Susquehanna River at Jersey Shore site (fig. 13; Roland and Hoffman, 2011). Again, while this comparison is a qualitative one, the results are much more detailed using the 1/9-arc-second data derived from "light and detection ranging (lidar) data. This site was included among the sites within the United States chosen for intercomparison between the GFT and one-dimensional hydraulic modeling results (table 1; fig. 13).

High resolution data ( 5 meters or better) are desirable whenever possible, though they are costly to produce by lidar or photogrammetric methods. The 3-arc-second HydroSHEDS data, derived from SRTM to reliably represent river networks and basin boundaries, are available worldwide but cannot be used in many places because of excessive "burning" of the river network, which produces unrealistically large stream channel depths. The SRTM-FM remedies this excessive burning, but so far, has only been completed for the African Continent and the Ganges-Brahmaputra Basin. The Advanced Spaceborne Thermal Emission and Reflection Radiometer Global Digital Elevation (ASTER GDEM) data (ASTER GDEM Validation Team, 2009) are likewise available worldwide, and have 1-arc-second resolution, but they require repair of serious artifacts in the flood plain before inundation mapping can be done with the GFT. Both the SRTM and the ASTER GDEM data also are limited in their use for flood inundation mapping because of the "top of canopy" nature of these DEMs; the elevations in the datasets do not represent bare-earth elevations except in areas without trees or structures.

An attractive alternative, if time and resources are available, is interpolation of a new DEM from digitized contours and "blue lines" (representing the hydrographic network) captured from conventional topographic maps. Digitization of original mylar separates, corresponding to the different color layers on the printed maps is ideal. The result is a DEM free of the "top of canopy" noise present in satellite data like SRTM and the ASTER GDEM, because most topographic maps are based on photogrammetric compilation that can be done, in most settings, to represent bareearth elevations. Creation of a DEM from digitized contours and blue lines was done in the Limpopo River basin of Mozambique for flood mapping after large floods in 2000. The available 1:50,000-scale maps were used as the source for creation of a new 90-meter DEM, that was subsequently used to make inundation maps for flood preparedness and response (Instituto Nacional de Gestão de Calamidades and others, 2002). 


\section{Flood risk map for Afgooye - $\mathbf{5 0}$ year return period}
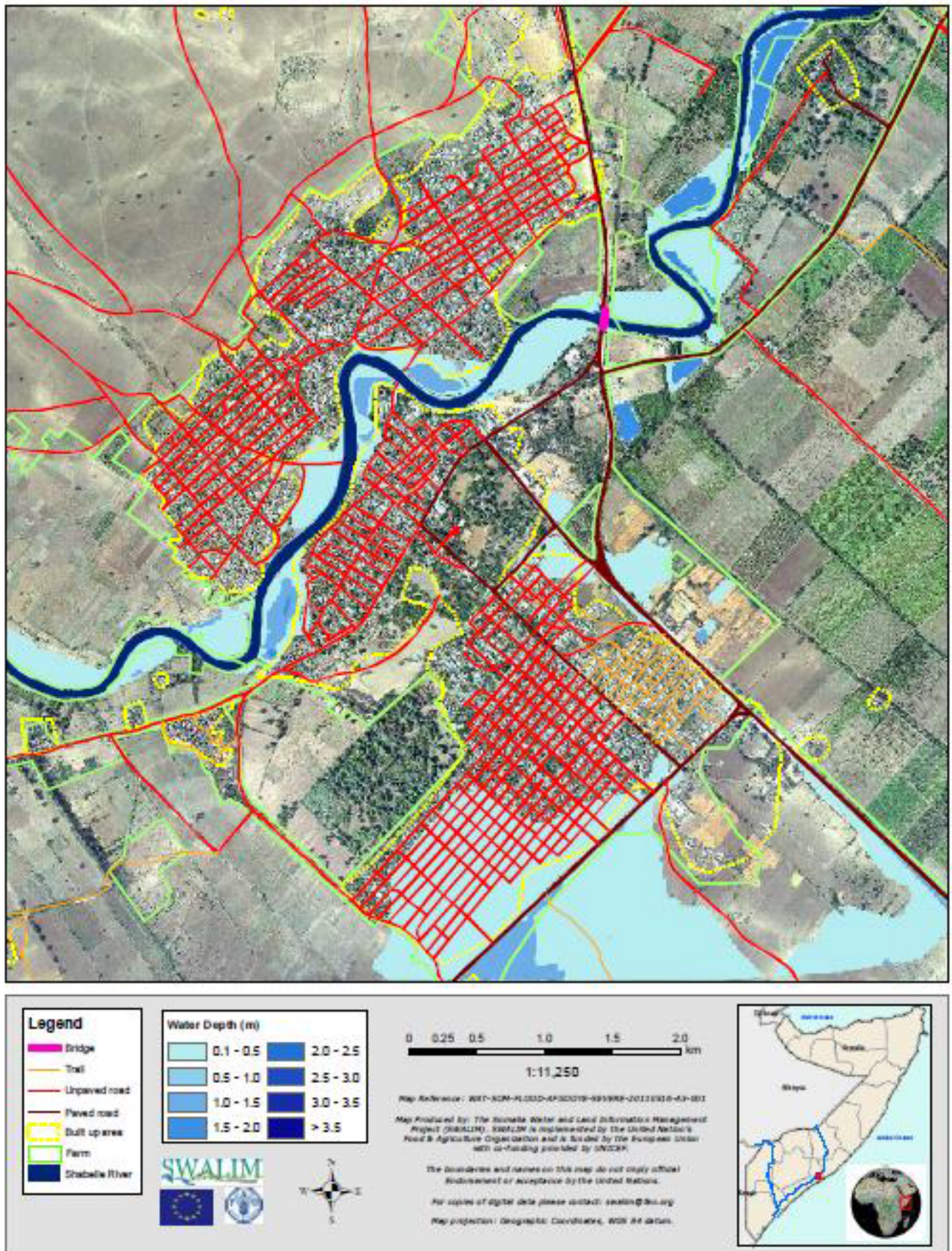

Figure 17. Map of the likely inundation pattern for the 50-year (2 percent probability) flood at Afgooye, Somalia, on the Shabelle River near Mogadishu, prepared by FAO SWALIM using the GIS Flood Tool (GFT). 

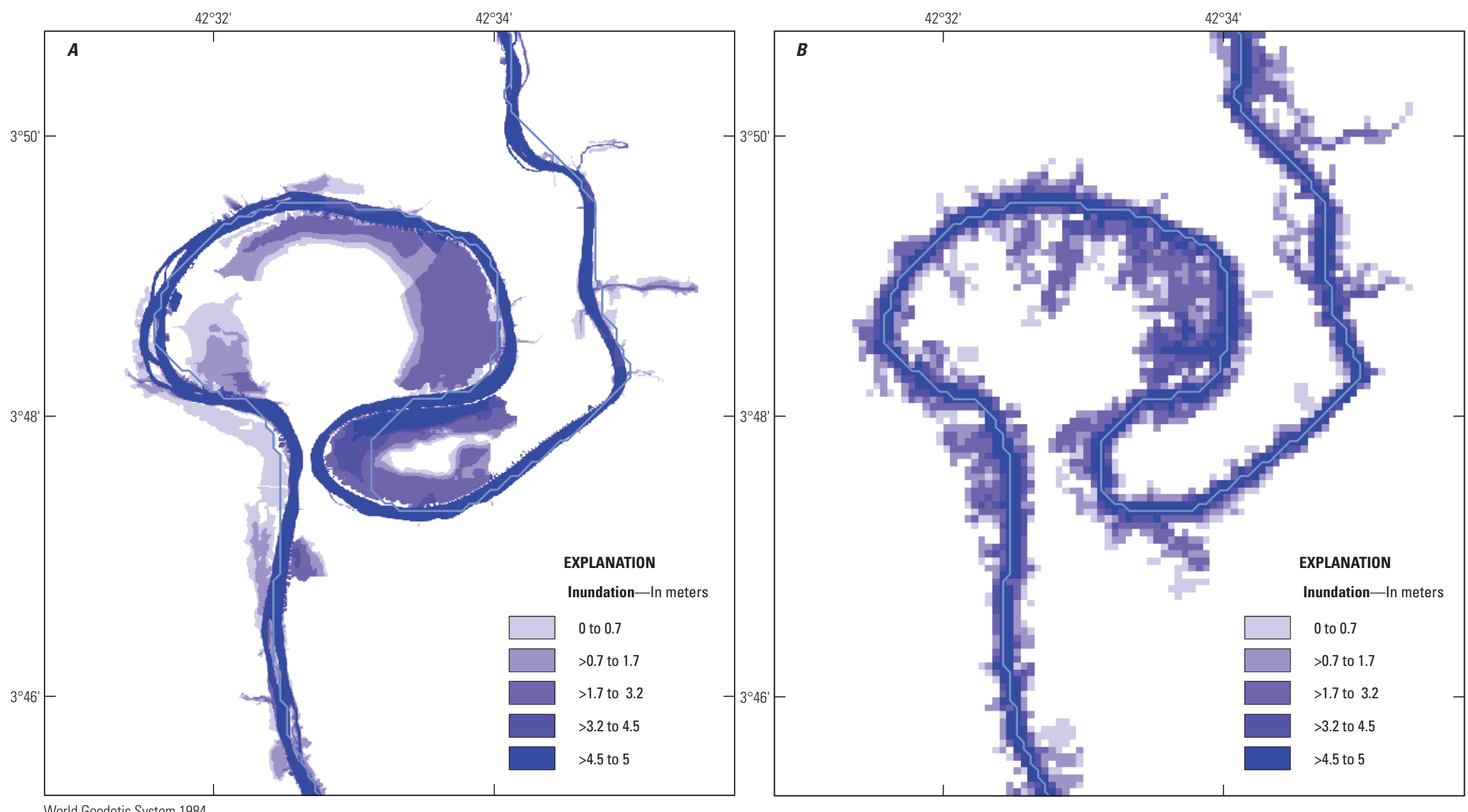

ก

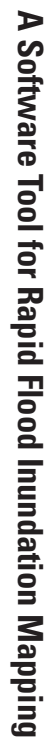

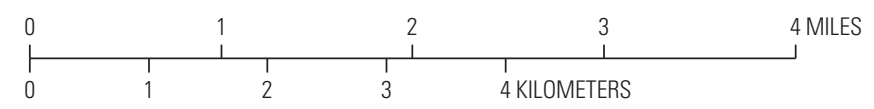

Figure 18. Comparison of the flood inundation maps produced with the GIS Flood Tool (GFT) for the Juba River at Luuq in Somalia produced using A, 10-meter DEM (left panel) and $B$, the 3-arc-second (about 90-meter) SRTM-FM DEM. 


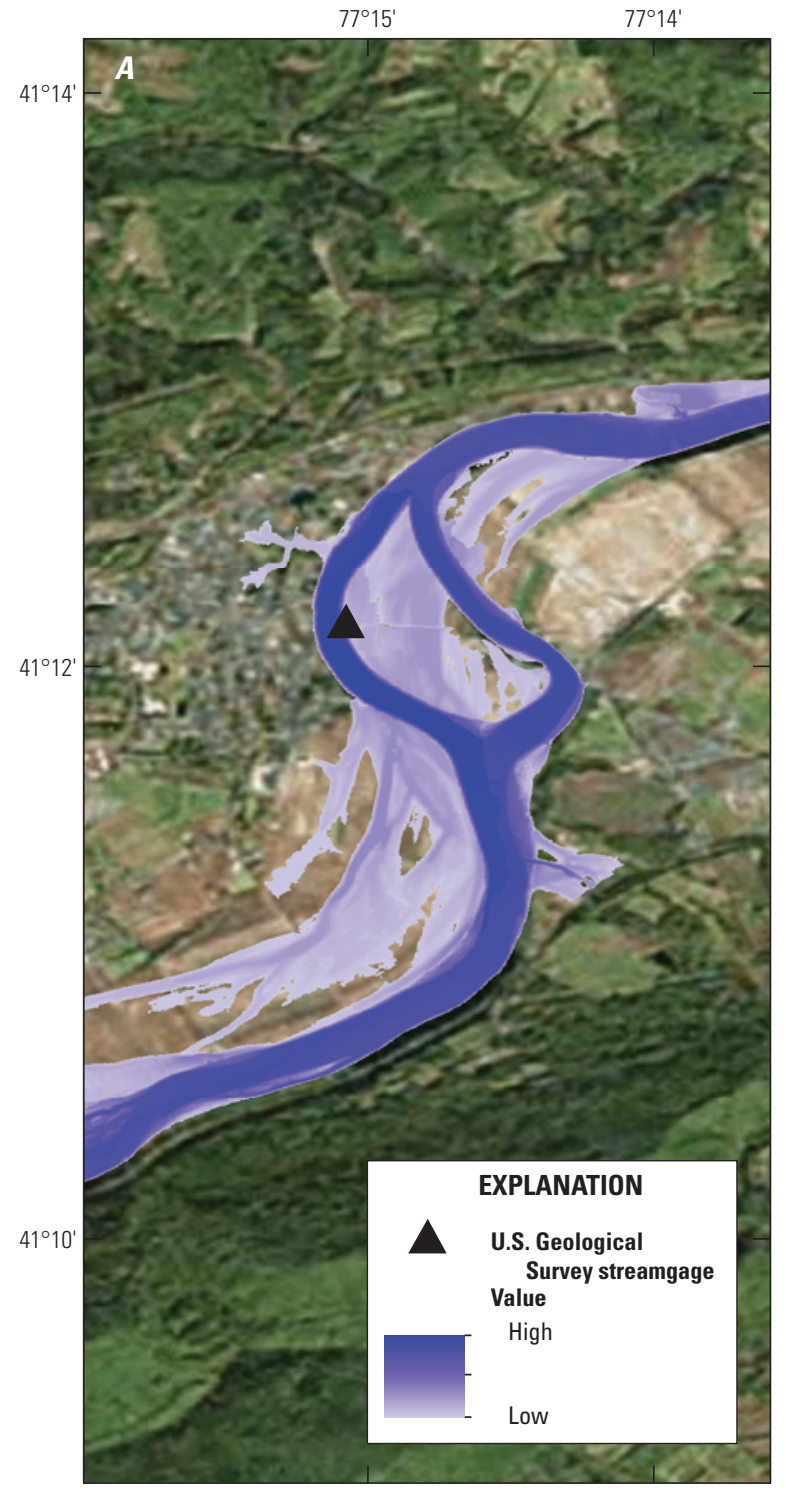

Base from Esri and Digital Globe digital data North American Datum of 1983 (NAD 83)
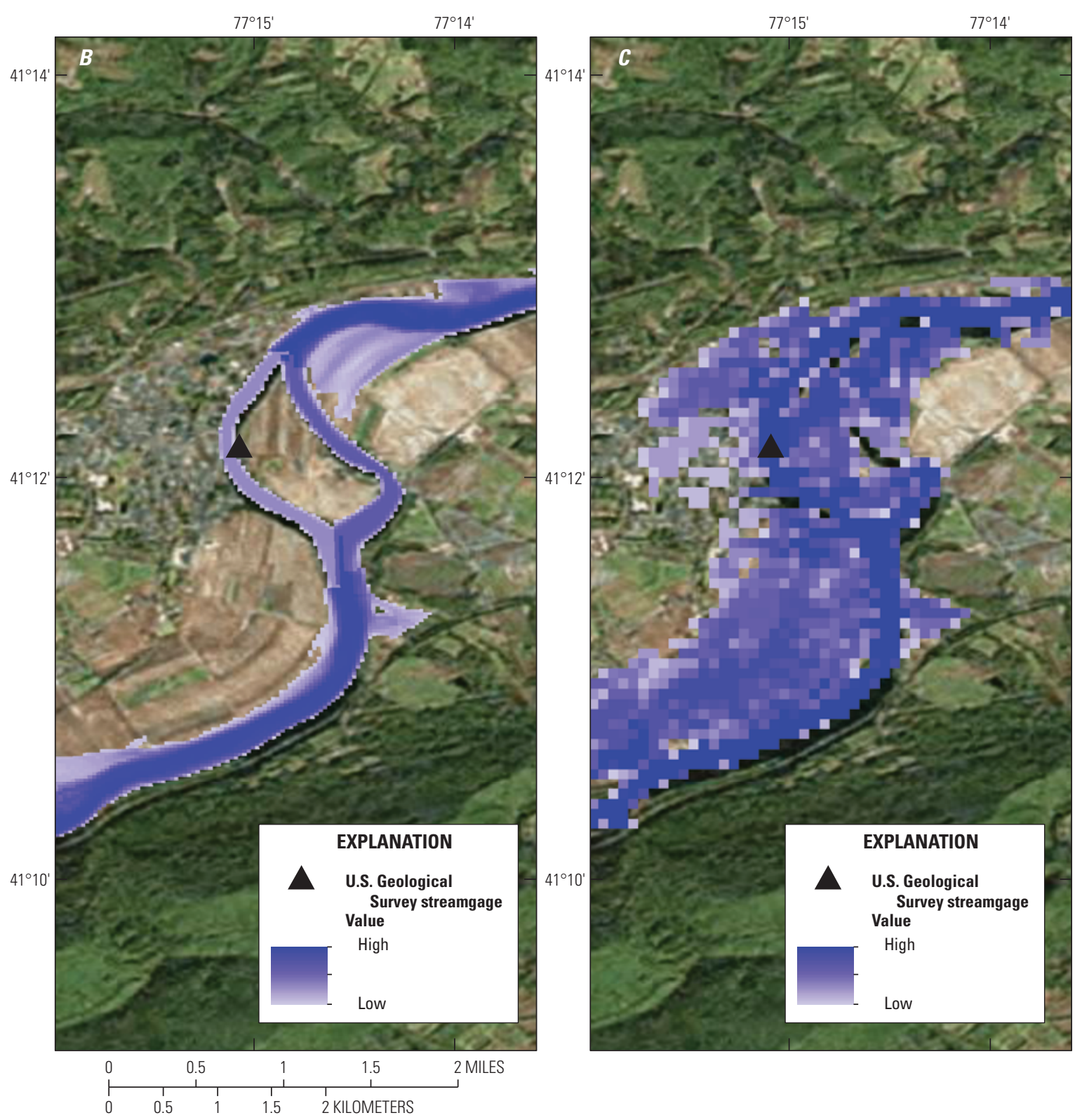

Figure 19. Inundation patterns generated for a discharge of 3,370 cubic meters per second for the West Branch Susquehanna River at Jersey Shore, Pennsylvania (USGS streamgage 01549760 ) using the GIS Flood Tool (GFT) with DEMS with resolutions of $A, 5$-meters; $B, 30$-meters; and $C$, 90-meters. 


\section{Placement and Number of Cross Sections}

The GFT automatically generates a cross section for each stream segment in a dataset being processed. The software attempts to automatically position cross sections at appropriate locations along the stream, and to orient them in a reasonable direction, perpendicular to the direction of flow; however, since the process is automatic, the results are sometimes not optimal. Therefore, the user should examine the positioning of cross sections and, if necessary, move some of the cross sections before proceeding with the rest of the processing. A cross section should be representative of the general shape of the entire reach, and should be positioned orthogonally with respect to the direction of the streamline near the cross section. To achieve the best placement for the cross sections, the GFT allows the user to move a cross section upstream or downstream to another location on the streamline. The GFT also allows the user to rotate the cross section to achieve a good orthogonal orientation.

If the shape of the land adjacent to a stream segment is highly variable, it is best to increase the number of cross sections along that reach. The GFT allows the user to add cross sections by dividing the stream reaches into shorter segments to reduce the variability of landform shape that each cross section must represent. Using more cross sections seems to produce better results than using fewer cross sections. This improvement comes in spite of the fact that the GFT does not model backwater or drawdown effects; some short, steep reaches that should be affected by backwater will underestimate inundation, and short, flat reaches might overestimate inundation. The noted improvement shows that having a representative cross section for each of many small reaches is more important than the limited benefit of averaging the slope over a long reach to avoid discontinuities. Although the use of many small cross sections may at times produce discontinuities in the flood extent maps between reaches, overall it allows the tool to represent more accurately the inundation throughout the river better than using just a few cross sections. Similar to other one-dimensional hydraulic models, increasing the number of sections beyond a certain point eventually fails to improve model results. The balance needed when selecting cross sections, and thereby defining reaches, is to have a sufficient number of well-located cross sections to represent the variability in channel shape, and to place the cross sections such that each reach retains something of the overall slope of the surrounding channel reaches.

\section{Offset for Within-Channel Flow}

Application of the Manning equation assumes that the cross section used represents the complete shape of the channel, including the part below the water surface. The use of a DEM to derive a cross section, however, is subject to the limitation that there is usually no bathymetric information in the dataset. The lack of bathymetric information in the DEM means that the calculation from the Manning equation is estimating stage for a discharge that is above and beyond that which is implied by the elevation of the river as represented in the DEM. In most cases, the flood discharge being mapped is much larger than within-channel flow and, therefore, the flooding primarily happens on the adjacent flood plain; however, it is good practice to attempt to estimate the amount of withinchannel discharge implied by the DEM elevation of the water surface and account for this offset when characterizing the mapped pattern of inundation.

If the area being mapped is near a streamgage, estimation of the discharge offset is straightforward, especially if the date of acquisition of the DEM data is known (for example, SRTM data were collected during February 2000). The streamflow record, if available, must be consulted and an appropriate discharge for the date of acquisition of the DEM selected; for example, if the objective is to map the inundation associated with a flow of $1,000 \mathrm{~m}^{3} / \mathrm{s}$, and the streamflow record indicates that the DEM represents a water-surface elevation associated with a discharge of $100 \mathrm{~m}^{3} / \mathrm{s}$, then the Manning calculation is made assuming $900 \mathrm{~m}^{3} / \mathrm{s}$.

If there are streamflow records available and satellite or airborne imagery showing the extent of inundation for a specific flood, then a match can be interpreted between the observed inundation pattern and a pattern in one of the maps in a library generated by the GFT. The offset, then, is the difference in discharge recorded on the date of imagery acquisition, and the discharge from the GFT depth-discharge curve for the GFT map that best matches the inundation observed in the imagery.

If there is no nearby streamgage, which is often the case, then a practical approach is to estimate the magnitude of bankfull flow, and assume that the bankfull flow is the discharge represented by the DEM elevation. Bankfull flow can be associated with a momentary maximum flow that has an average recurrence interval of 1.5 years as determined using a flood frequency analysis (Dunne and Leopold, 1978). Such a discharge can be estimated at ungaged sites using regional-regression equations if the ungaged sites have basin characteristics (for example, upstream area and mean annual precipitation) as independent variables, similar to those available with StreamStats (U.S. Geological Survey, 2012) in the United States, and for areas outside the United States, as presented in Meigh and others (1997).

\section{Summary and Conclusions}

The GIS Flood Tool (GFT) when applied with the Shuttle Radar Topography Mission for Flood Mapping (SRTM-FM) digital elevation mode (DEM) or an appropriate local DEM is an effective, rapid assessment tool for flood inundation mapping. The GFT can fill an important gap for communities that lack flood inundation mapping by providing a first-estimate of inundation zones, pending availability of resources to complete an engineering study. The GFT can also identify priority areas for application of scarce flood inundation mapping resources. 
The GFT has been used successfully in data-sparse areas of the world. By using this software, initial estimates of flood levels corresponding to various return periods can be developed with minimal effort. The resulting estimates of flood extent have multiple uses in planning; for example, before completing detailed inundation studies, it is not always clear what extent of flooding needs to be considered for data collection, including topographic and economic surveys. Because these surveys can be costly and the cost directly relates to the extent of the survey, it is important to have an initial assessment of the flood extent to limit unnecessary surveying while assuring adequate coverage. The GFT can provide a rapid review of initial flood results, that, when coupled with an assessment of the location of development, can also help focus on areas of greatest effect for additional study.

Although the software tool is intended to be relatively simple to use, it still needs to be understood and applied with careful judgment, and with the oversight or review of a qualified hydraulic engineer. Its rapid assessment ability comes with important simplifications in the hydraulic simulation that require this oversight and understanding to correctly apply the model and interpret the results. The GFT model's one-dimensional hydraulic equations are subject to the limitations of any one-dimensional hydraulic model, including an inability to properly represent diverging flow in flat flood plains.

It is important that the interpretation of flood maps prepared with the GFT take into account the assumptions and limitations of the methods and input data. Geographic information system technologies can be used to display results obtained from coarse resolution analyses on high resolution backgrounds, potentially conveying more precision than is warranted by the inputs; therefore, care must be taken that appropriate conclusions be drawn from GFT model results, and that consequent decisions are consistent with the expected precision and accuracy of the results.

\section{References Cited}

Arcorace, Mauro, Dell-Oro, L., Bjorgo, E., Piemontese, L., and Dave, R., 2015, SRTM-FM-A hydrologically conditioned SRTM dataset for flood mapping - A case study over the Zambezi River Basin, Mozambique and Malawi: The United Nations Office for Disaster Risk Reduction, accessed November 2015 at http://www.preventionweb.net/files/ workspace/7935_arcoracezambeziriverbasin.pdf.
ASTER GDEM Validation Team, 2009, ASTER global DEM validation summary report: Land Processes Distributed Active Archive Center Web site, 28 p., accessed June 2015 at https://pdaac.usgs.gov/sites/default/files/public/aster/ docs/ASTER_GDEM_Validation_Summary_Report.pdf.

Benedict, S.T., Caldwell, A.W., and Clark, J.M., 2013, Floodinundation maps for the Saluda River from Old Easley Bridge Road to Saluda Lake Dam near Greenville, South Carolina: U.S. Geological Survey Scientific Investigations Map 3244, 15 sheets, 7-p. pamphlet. [Also available at http://pubs.usgs.gov/sim/3244/.]

Czuba, C.R., Fallon, J.D., Lewis, C.R., and Cooper, D.F., 2014, Development of flood-inundation maps for the Mississippi River in Saint Paul, Minnesota: U.S. Geological Survey Scientific Investigations Report 2014-5079, 24 p. [Also available at http://dx.doi.org/10.3133/sir20145079.]

De Roo, Ad; Barredo, Jose; Lavalle, Carlo; Bodis, Katalin; and Bonk, Rado, 2007, Potential flood hazard and risk mapping at Pan-European scale in Peckham R.J., and Jordan, Gyozo, eds., Digital terrain modeling - Lecture notes in Geoinformation and Cartography 2007: Berlin, Springer Berlin Heidelberg, p. 183-202.

Dunne, T. and Leopold, L.B., 1978, Water in environmental planning: New York, W.H. Freeman and Company, 838 p.

Esri, 2014, ArcMap 10.2: Redlands, Calif., Esri.

Flynn, R.H., Johnston, C.M., and Hayes, Laura, 2012, Flood-inundation maps for the Suncook River in Epsom, Pembroke, Allenstown, and Chichester, New Hampshire: U.S. Geological Survey Scientific Investigations Map 3196, 10-p. pamphlet, 20 sheets, scale 1:24,000. [Also available at http://pubs.usgs.gov/sim/3196/.]

Fowler, K.K., 2014, Flood-inundation maps for the East Fork White River near Bedford, Indiana: U.S. Geological Survey Scientific Investigations Map 3274, 20 sheets, 8-p. pamphlet. [Also available at http://dx.doi.org/10.3133/sim3274.]

Gesch, D., Oimoen, M., Greenlee, S., Nelson, C., Steuck, M., and Tyler, D., 2002, The National Elevation Dataset: Photogrammetric Engineering and Remote Sensing, v. 68, no. 1, p. 5-11.

Herold, C., and Mouton, F., 2011, Global flood hazard mapping using statistical peak-flow estimates: Hydrology and Earth System Science Discussion, 56 p., accessed June 2015 at https://www-fourier.ujf-grenoble.fr/ mouton/Publis_HDR_applis/Herold_Mouton.pdf. 
Hoppe, H.L., and Watson, K.M., 2012, Flood-inundation maps for the Saddle River from Rochelle Park to Lodi, New Jersey, 2012: U.S. Geological Survey Scientific Investigations Map 3221, 7 p., 11 sheets, scale 1:12,000. [Also available at http://pubs.usgs.gov/sim/3221.]

Instituto Nacional de Gestão de Calamidades, U.S. Agency for International Development, and University Eduardo Mondlane, 2002, Atlas for disaster preparedness and response in the Limpopo Basin, Maputo: accessed June 2015 at http://edmc1.dwaf.gov.za/library/limpopo/ index.htm.

Iowa Flood Information System, accessed February 2016 at http://ifis.iowafloodcenter.org/ifis/main/?m=Iowa_City.

Jarvis, A., Reuter, H.I., Nelson, A., and Guevara, E., 2008. Hole-filled SRTM for the globe, version 4: available from the CGIAR-CSI SRTM 90m Database, accessed June 2015 at http://srtm.csi.cgiar.org.

Lehner, B., Verdin, K.L., and Jarvis, A., 2008, New global hydrography derived from spaceborne elevation data: Eos, Transactions American Geophysical Union, v. 89, no. 10, p. 93-94.

Lombard, P.J., 2013, Flood-inundation maps for the Wabash River at Terre Haute, Indiana: U.S. Geological Survey Scientific Investigations Map 3232, 22 sheets, 7-p. pamphlet. [Also available at http://pubs.usgs.gov/sim/3232/.]

Manning, R., 1891, On the flow of water in open channels and pipes: Transactions of the Institution of Civil Enginers of Ireland, 20, 161-207.

Meigh, J.R., Farquharson, F.A.K., and Sutcliffe, J.V., 1997, A worldwide comparison of regional flood estimate methods and climate: Hydrological Sciences, v. 42, no. 2, p. 225-244.

Murphy, E.A., Soong, D.T., and Sharpe, J.B., 2012, Floodinundation maps for a nine-mile reach of the Des Plaines River from Riverwoods to Mettawa, Illinois: U.S. Geological Survey Scientific Investigations Report 2012-5227, 17 p. [Also available at http://pubs.usgs.gov/sir/2012/5227.]

National Oceanic and Atmospheric Administration, 2011, NOAA partnered guidelines for the development of advanced hydrologic prediction service flood inundation mapping: National Oceanic and Atmospheric Administration, $40 \mathrm{p}$. with appendixes, accessed February 2016 at http://water.weather.gov/ahps/NOAA_AHPS_Guidelines_ Final_2011_v3.pdf.

Nobre, A.D., Cuartas, L.A., Hodnett, M., Renno, C.D., Rodrigues, G., Silveira, A., and Waterloo, M., 2011, Height above the nearest drainage-A hydrologically relevant new terrain model: Journal of Hydrology, v. 404, p. 13-29.
Roland, M.A., and Hoffman, S.A., 2011, Development of flood-inundation maps for the West Branch Susquehanna River near the Borough of Jersey Shore, Lycoming County, Pennsylvania: U.S. Geological Survey Scientific Investigations Report 2010-5057, 9 p.

Roland, M.A., Underwood, S.M., Thomas, C.M., Miller, J.F, Pratt, B.A., Hogan, L.G., and Wnek, P.A., 2014, Flood inundation maps for the Susquehanna River near Harrisburg, Pennsylvania, 2013: U.S. Geological Survey Scientific Investigations Report 2014-5046, 17 p. [Also available at http://dx.doi.org/10.3133/sir20145046.]

Storm, J.B., 2012, Flood-inundation maps for the Leaf River at Hattiesburg, Mississippi: U.S. Geological Survey Scientific Investigations Map 3228, 8-p. pamphlet, 13 sheets. [Also available at http://pubs.usgs.gov/sim/3228/.]

Taylor, P.J., 1977, Quantitative methods in geography-An introduction to spatial analysis: Prospect Heights, Ill., Waveland Press, 375 p.

United Nations Office for Disaster Risk Reduction, 2009, Risk and poverty in a changing climate: Invest today for a safer tomorrow: United Nations Office for Disaster Risk Reduction, 2009 Global Assessment Report on Disaster Risk Reduction, 207 p., accessed June 2015 at http:// www.preventionweb.net/english/hyogo/gar/report/index. php?id=9413.

U.S. Army Corps of Engineers, Hydrologic Engineering Center, 2010, HEC-RAS River analysis system, hydraulic reference manual, version 4.1: U.S. Army Corps of Engineers, [variously paged], accessed June 2015 at http://www. hec.usace.army.mil/software/hec-ras/documentation/HECRAS_4.1_Reference_Manual.pdf.

U.S. Geological Survey, 2012, The StreamStats program: U.S. Geological Survey, accessed June 2015 at http:// streamstats.usgs.gov.

Publishing support provided by: Rolla Publishing Service Center

For more information concerning this publication, contact: U.S. Geological Survey Earth Resources Observation and Science (EROS) Center

47914 252nd Street Sioux Falls, South Dakota 57198 (605) 594-6151

Or visit the EROS Center Web site at: http://eros.usgs.gov/ 



\section{$\frac{\mathbb{3}}{3}$}

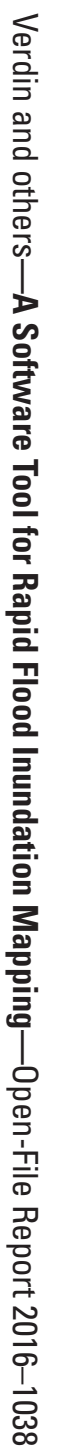

